\title{
F10Tを用いた高カボルト摩擦接合継手に おけるナット回転角法の適用の検討
}

\author{
白旗 弘実 1 - 南 邦明 2 ・藤野 大地 3 ・宮井大輔 4 ・矢野 将太 5 ・横田 涉 6 \\ 1正会員 東京都市大学教授 工学部都市工学科（₹158-8557 東京都世田谷区玉堤1-28-1） \\ E-mail: hshiraha@tcu.ac.jp \\ 2正会員 鉄道建設・運輸施設整備支援機構 設計部（†231-8315 神奈川県横浜市中区本町6-50-1） \\ E-mail: minami.kun-e27b@jrtt.go.jp \\ 3 正会員 川田工業 鋼構造事業部 技術部（干114-8562 東京都北区滝野川1-3-11） \\ E-mail: daichi.fujino@kawada.co.jp \\ 4正会員 横河ブリッジ設計本部 東京設計第一部（†273-0026 千葉県船橋市山野町27） \\ E-mail: miyai@yokogawa-bridge.co.jp \\ 5 正会員 川田テクノシステム 総合技術部 東京技術部（テ114-0023 東京都北区滝野川6-3-1） \\ E-mail: s-yano@kts.co.jp \\ 6非会員 東京都 下水道局 東部第一下水道事務所（干135-0016 東京都江東区東陽7-1-14） \\ (研究当時 東京都市大学工学部 都市工学科) \\ E-mail: Wataru_Yokota@member.metro.tokyo.jp
}

\begin{abstract}
本論文は，F10Tを用いナット回転角法でボルト締付けを行った高力ボルト摩擦接合接手に関する実験的 研究である. 本研究では, 無機ジンクリッチペイントを施した同継手のナット回転角法の適用に向けた基 礎データを取得することを目的として，まず，一次締めに関して，スナッグタイト（人力で力いっぱいで のボルト締付け）の適用性を調べた。 次に，ボルト径およびボルト長をパラメータとした導入軸力試験お よびリラクセーション試験を行い, 適切なボルト軸力, 寸なわち, ボルトねじ部が降伏域に入らないでリ ラクセーション後も設計ボルト軸力を満足できるナット回転角を提案した. さらに, 提案したナット回転 角を用いてすべり試験体を作成し，すべり耐力試験を実施し，F10Tのナット回転角法の適用に向けた検討 を行った。
\end{abstract}

Key Words : bolted connection, nut rotation method, F10T, relaxation, slip coefficient, snug tight

\section{1. はじめに}

道路橋示方書 ${ }^{1)}$ (以下，道示）および鉄道構造物等 設計標準 ${ }^{2}$ (以下，鉄道標準）において，高力ボルト 摩擦接合継手におけるボルト締付け法は, トルク法, ナット回転角法および耐力点法が示されている3). 現 在, 耐力点法を用いることはほとんどなく, 一般にト ルク法が適用されるが，防食法に金属溶射を適用する 場合には，溶融亜鈶めつきボルトF8T（以下，めつき ボルト）を使用するので，その際，ナット回転角法が 適用される. 理由としては，めっきボルトの締付け作 業において，ボルトやナットに付着した亜鉛の膜厚の ばらつき等の影響で，導入軸力にばらつきが生じるこ と, リラクセーションによる軸力低下が大きいことが
あげられる.よって，導入軸力が高くなるナット回転 角法が用いられる.

道示および鉄道標準において，ナット回転角法を用 いる場合, ナット回転角は $120^{\circ}(L \leqq 5 d(L:$ ボルト長 さ， $d$ : ボルト径))を規定している.ただし，これはブ ラスト処理されためつき面を対象とした規定であり1), 著者の 1 人は，例えば，接触面に溶射あるいはりん酸 塩処理しためっき面では，ナット回転角は90 $(L \leqq 5 d)$ がよいことを示した ${ }^{4), 5)}$ 。これは，接触面によってリ ラクセーションによる軸力低下特性が異なるからであ り，適切なボルト軸力が期待できるナット回転角は接 触面によって異なると考えられる.

現在，鋼橋の建設工事では，使用ボルトはトルシア 形ボルトS10Tを使用しているケースが最も多い.これ 
表-1 使用鋼材の機械的性質および化学成分(スナッグタイト試験)

\begin{tabular}{|c|c|c|c|c|c|c|c|c|c|c|}
\hline \multirow[b]{2}{*}{ 鋼種 } & \multirow[b]{2}{*}{$\begin{array}{l}\text { 板厚 } \\
(\mathrm{mm})\end{array}$} & \multicolumn{3}{|c|}{ 機械的性質 } & \multicolumn{5}{|c|}{ 化学成分 $(\%)$} & \multirow[b]{2}{*}{ 適用場所 } \\
\hline & & \begin{tabular}{|l|} 
耐力 \\
$\left(\mathrm{N} / \mathrm{mm}^{2}\right)$
\end{tabular} & $\begin{array}{l}\text { 引張強度 } \\
\left(\mathrm{N} / \mathrm{mm}^{2}\right)\end{array}$ & 伸び(\%) & C & $\mathrm{Si}$ & Mn & $\mathrm{P}$ & S & \\
\hline SM490YA & 9 & 457 & 535 & 22 & 0.15 & 0.19 & 0.108 & 0.023 & 0.007 & A1の母板・連結板 \\
\hline SM490YA & 12 & 482 & 537 & 22 & 0.14 & 0.18 & 0.110 & 0.016 & 0.003 & A20連結板 \\
\hline SM490YB & 19 & 461 & 542 & 23 & 0.15 & 0.19 & 0.107 & 0.016 & 0.005 & A3の連結板 \\
\hline SM490YB & 22 & 426 & 513 & 25 & 0.15 & 0.19 & 0.108 & 0.016 & 0.004 & A2の母板 \\
\hline SM490YB & 32 & 418 & 527 & 21 & 0.15 & 0.18 & 0.107 & 0.016 & 0.006 & A3の母板 \\
\hline
\end{tabular}

表-2 使用ボルトの機械的性質とトルク係数值(スナッグタイト試験)

\begin{tabular}{|c|c|c|c|c|c|c|c|c|c|c|c|}
\hline \multirow{3}{*}{ ボルト径 } & \multirow{3}{*}{$\begin{array}{c}\text { 首下長さ } \\
(\mathrm{mm})\end{array}$} & \multirow{3}{*}{$\begin{array}{c}\text { 有効 } \\
\text { 断面積 } \\
\left(\mathrm{mm}^{2}\right)\end{array}$} & \multicolumn{6}{|c|}{ ボルト } & \multirow{2}{*}{\begin{tabular}{|l|} 
ナット \\
製品
\end{tabular}} & \multirow{2}{*}{\begin{tabular}{|l|} 
座金 \\
製品
\end{tabular}} & \multirow{3}{*}{$\begin{array}{c}\text { トルク } \\
\text { 係数値 } \\
\text { (平均値) }\end{array}$} \\
\hline & & & \multicolumn{4}{|c|}{ 4号試験片 } & \multicolumn{2}{|c|}{ 製品 } & & & \\
\hline & & & $\begin{array}{l}\text { 耐力 } \\
\left(\mathrm{N} / \mathrm{mm}^{2}\right)\end{array}$ & \begin{tabular}{|l} 
張強度 \\
$\left(\mathrm{N} / \mathrm{mm}^{2}\right)$
\end{tabular} & $\begin{array}{l}\text { 伸び } \\
(\%)\end{array}$ & \begin{tabular}{|l} 
絞り \\
$(\%)$
\end{tabular} & \begin{tabular}{|l} 
引張荷重 \\
$(\mathrm{kN})$
\end{tabular} & $\begin{array}{l}\text { 硬さ } \\
\text { (HRC) }\end{array}$ & $\begin{array}{l}\text { 硬さ } \\
\text { (HRC) }\end{array}$ & $\begin{array}{l}\text { 硬さ } \\
\text { (HRC) }\end{array}$ & \\
\hline \multirow{3}{*}{ M22 } & 70 & \multirow{3}{*}{303} & 993 & 1050 & 18 & 69 & 328 & 32 & 30 & 40 & 0.130 \\
\hline & 90 & & 987 & 1052 & 18 & 69 & 323 & 32 & 29 & 40 & 0.130 \\
\hline & 110 & & 1024 & 1056 & 18 & 69 & 324 & 33 & 30 & 40 & 0.129 \\
\hline
\end{tabular}

は，作業効率がよいと考えられているからであるが, 日々, 締付け作業前に 5 本のボルト軸力の導入軸力の 確認作業や, 締付け後は, 全数ピンテール破断面のグ ラインダー処理作業を行っているのも事実である。一 方，ナット回転角法は，機械締めの専用レンチで行い， 締付け精度も高く, さらに, 日々の締付けの前作業や 締付け後の作業もなく, ナット回転角法を適用すれば 作業効率が向上すると考えられる．ただし，道示や鉄 道標準では，ナット回転角法の適用は F8T のみであり 強度の高い F10T での適用は認められていない.これ は，ナット回転角法での締付けは，導入軸力が高くな り，遅れ破壊を懸念しているからである 6),7). これに ついては，道示ではボルト規定が初めて示された昭和 48 年度版から変更されていない.

F10T のナット回転角法の適用に向けた検討は，昭 和 41 年から JSSC の接合小委員会で行われた ${ }^{8)}$. ここ では，ナット回転角は $180^{\circ}$ が提案され，また，遅れ破 壊に関しては，通常の使用条件であれば生じる可能性 は少ないとし，適用事例を増やして一般化させること がよいとされた。ここでいう通常の使用条件とは，具 体的な記述はなかったが，高温水中下といった特殊な 腐食環境で促進試験を行っていたので，わが国におい て起こりうる気温, 飛来塩分, 湿度などの条件下とい うことと思われる. その後，締付け作業および施工検 査の簡素化を図ることを目的とし，実構造物での適用 に関する検討も行われ 9),10)，ナット回転角 $180^{\circ}$ で実施 工が行われた ${ }^{11)}$. その後 40 年, F10T でのナット回転 角法を適用した事例は著者らの知る限りない.また, 適用された当時の接触面は，黒皮を除去した粗面状態 であり, 現在の主流である厚膜型無機ジンクリッチペ
イント（以下，無機ジンク）を施した接触面で F10T を適用した適用事例はなく，また，その適用性は不明 である。

ナット回転角法の施工の際には，鉄道標準 2)では $150 \mathrm{Nm}$ (M22 の場合)といった一次締付けトルク值の規 定がある一方で，道示 1)では「接触面の肌隙がなくな る程度にトルクレンチで締めた状態又は組み立て用ス パナで力いっぱい締めた状態」から回転角を与える記 述となっている. 肌隙のない状態をスナッグタイトと いうが，この道示で規定している状態が定量的なトル ク量あるいはボルト軸力とどのような関係になってい るかの調査や報告は著者らの知る限りない.

本研究は，F10T を用いナット回転角法でボルト締 付けを行った高力ボルト摩擦接合接手の適用に向けた 基礎データを取得し，これらをもとにナット回転量に ついて検討することを目的に行った実験的研究である. 本実験では，始めにスナッグタイト試験を行った。つ まり，組み立て工具で力いっぱい締めた状態がどれだ けの軸力導入となるのかを調べ，試験で適用可能か検 討した。 その後, F10T を用い無機ジンクを施した試 験体を作成し，ボルト径，ボルト長およびナット回転 角をパラメータとした導入軸力試験およびリラクセー ション試験を行い, 適切なボルト軸力, すなわち, ボ ルト軸部が降伏域に入らないでリラクセーション後も 設計ボルト軸力を満足できるナット回転角を提案した. 次に，提案したナット回転角ですべり試験体を作成し， すべり耐力試験を実施した。 これらの結果から, 提案 したナット回転角の妥当性を検証し, F10T のナット 回転角法の適用に向けた検討を行った。 


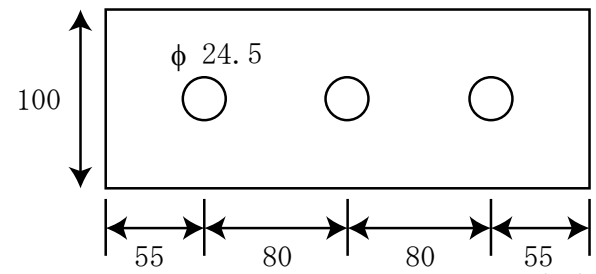

(mm)

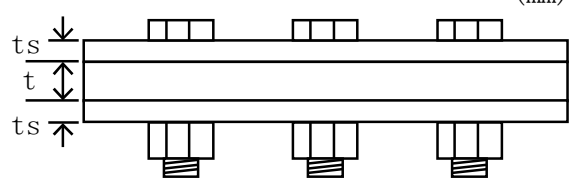

図-1 スナッグタイト試験片

表-3＼cjkstart試験体の板厚およびボルトの組合せ

\begin{tabular}{|l|r|l|l|}
\hline \multirow{2}{*}{$\begin{array}{c}\text { 試験 } \\
\text { 体名 }\end{array}$} & \multicolumn{2}{|c|}{ 板厚 $(\mathrm{mm})$} & \multirow{2}{*}{$\begin{array}{l}\text { ボルト } \\
\text { サイズ }\end{array}$} \\
\cline { 2 - 3 } A1 & 9 & 連結板(ts) & イ \\
\hline A2 & 22 & 9 & M22-L70(3.2d) \\
\hline A3 & 32 & 12 & M22-L90(4.1d) \\
\hline
\end{tabular}

( 母板 )

\section{$\times \mathrm{O} \times \mathrm{OP} \times \mathrm{Ox}$}

x: 計測位置であり，円孔端から $20 \sim 30 \mathrm{~mm}$ を測定

図-2 無機ジンク厚さ測定箇所

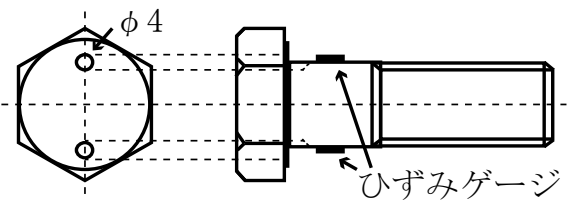

図-3 ひずみゲージの取り付け

\section{2. スナッグタイト試験}

\section{（1）試験体の使用材料および形状・寸法および種類}

試験に用いた鋼材および高力ボルトの材料特性をそ れぞれ表-1 および表-2に示す。使用ボルトは六角ボル ト F10T-M22 であり，ボルト長は 70，90 および $110 \mathrm{~mm}$ の三種類である. 表-2 のボルトの機械的性質 は 3 本のボルトの平均值である. 試験体を図-1 に示す. 表-3 に示すような連結板および母板で三種類の組み合 わせを用意し，それに応じたボルト長のボルトを締め た. 表-3のボルトサイズで示す $d$ は，ボルトの呼び径 であり，たとえば $3.2 d$ とは，首下長さ $70 \mathrm{~mm}$ が径の 3.2 倍であることを意味している. 図-1 に示すように， 一つの試験体には 3 つボルト孔があけられている.
表-4 スナッグタイト試験片の膜厚

\begin{tabular}{|l|r|r|r|r|}
\hline \multirow{2}{*}{$\begin{array}{c}\text { 試験 } \\
\text { 体名 }\end{array}$} & \multicolumn{4}{|c|}{ 塗装膜厚 $(\mu \mathrm{m})$} \\
\cline { 2 - 4 } & \multicolumn{3}{|c|}{ ボル番号 } & \multirow{2}{*}{ 平均 } \\
\cline { 2 - 4 } & No.1 & No.2 & No.3 & \\
\hline A1 & 88 & 87 & 77 & 84 \\
\hline A2 & 85 & 89 & 98 & 91 \\
\hline A3 & 87 & 88 & 87 & 87 \\
\hline
\end{tabular}

ボルトピッチ $(P) や$ 縁端距離 $(e)$ は，標準試験片 12)を参 考に決定した.

\section{(2) 塗装膜厚測定}

試験体には無機ジンクを塗装した。膜厚測定結果を 表-4 に示す．測定位置は，図-2 に示すようにボルト孔 周辺とし，測定数は，1つのボルト孔に対し，母板の 両面および添接板の片面各 2 点とし，試験体一体あた り計 24 点測定した. 1 点につき 5 回計測し，平均を取 った。測定時期は，塗装作業後とした。

膜厚は $75 \mu \mathrm{m}$ を設計厚さとしたが，計測值は 77〜 $98 \mu \mathrm{m}$ であり, 厚めの結果となった.

\section{(3) ボルト軸力の計測}

導入軸力の評価を行うため，ボルト軸部にひずみゲ ージを取り付け，ボルト軸力を計測した。なお，ボル 卜軸力の計測に際し，表-2 に示す 3 種のボルトそれぞ れに対し，荷重とひずみの関係から換算率を求めるキ ヤリブレーション試験を実施し，ひずみからボルト軸 力を算出するための換算率を求めた.

スナッグタイトの計測はボルト軸部に図-3 に示すよ うに，2 枚のゲージを貼付し，それらのゲージ出力 （ひずタ值）の平均值に換算率を乗じボル卜軸力を算 出した。ゲージ長は $5 \mathrm{~mm}$ である。その際，ボルト軸 部のひずみゲージの位置は，試験体として組み立てた 際に，なるべく母材板厚中央となるようにした.

\section{（4） ボルト軸力の締付け作業}

ボルトの締付けは，三社の橋梁製作会社の工場ある いは建設現場で行った。会社をここでは A 社，B 社， $\mathrm{C}$ 社と呼ぶことにするが，日常的にボルト締付けを行 っている作業員を $\mathrm{A}$ 社から 2 名, $\mathrm{B}$ 社では 3 名, $\mathrm{C}$ 社 では 6 名の合計 11 名が締付け作業を行った.

三社のうちの一社の作業状況を写真-1 に示すが，高 さ 70〜 $100 \mathrm{~cm}$ の机あるいは台に万力で試験片を固定し た. 最初のボルトを締める前にデータロガーのイニシ ヤルを取ったのち，3 本のボルトを連続的に締めた. 3 本のボルトの締付け順序は決まりをもうけず任意とし 


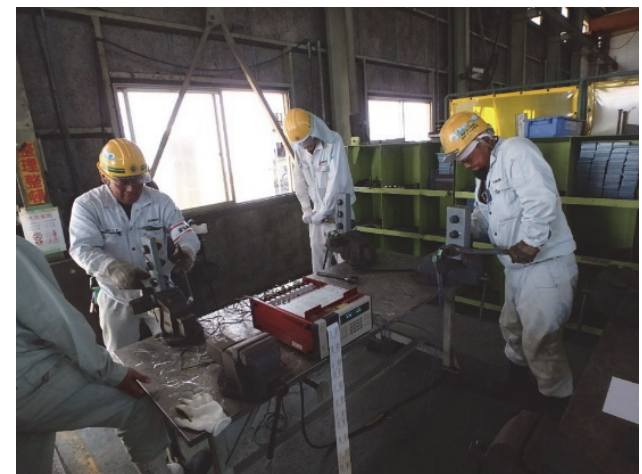

写真-1 スナッグタイト試験状況

た. 3 本のボルトを締め終わってからデータロガーで ひずみの記録を取った。

締付けにおいては，長さ $30 \sim 40 \mathrm{~cm}$ のラチェット， レンチなどを用いて, 各作業員が力いっぱいと感じる まで，つまり，これ以上自身の力でナットを回せない と判断したところまでとした.

これら一連の締付け作業を 1 人の作業員につき, 3 種類の試験片すべてのボルトを締付けるように同時に ローテーションしながら，何回か繰り返した，一社が 終わった後に, 試験体を他の会社に回送し, 次の一社 で締付け試験を行い，最後の会社に回送するという流 れで行った．三社ともに作業台の高さや工具による極 端な差がないようにした. 人力であることからボルト や試験体が塑性域に達することはないと判断し，再使 用した。ただし，ゲージのひずみ值が不安定になった 場合にはボルトを交換した. 最終的には $\mathrm{A}$ 社 108 件, $\mathrm{B}$ 社 80 件， $\mathrm{C}$ 社 53 件の合計 241 件の締付けデータを 得た.

\section{(5) ボルト軸力の分布}

ボルトの導入軸力を計算し，鉄道標準などで規定さ れている值との比較を行った. ボルトの軸力およびト ルクの関係は次の式で表される.

$$
N=\frac{T}{k d}
$$

ここに, $N$ はボルト軸力, $T$ はトルク,$k$ はトルク 係数, $d$ はボルト呼び径である. 使用したボルトの $k$ は表-2 の值を用いると，M22 の規定值である $150 \mathrm{Nm}^{2}$ に相当する軸力は $52 \mathrm{kN}$ であると算出された.

図-4はボルト軸力の頻度をボルト長ごとに示したも のである，たとえばL70は，首下長さ70mmのボルトで

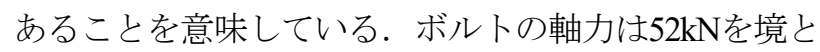
し， $5 \mathrm{kN}$ 範囲でまとめた。図-4より，ボルト軸力は 47〜 52，52〜 57kNあたりをおおむねピークとした分布

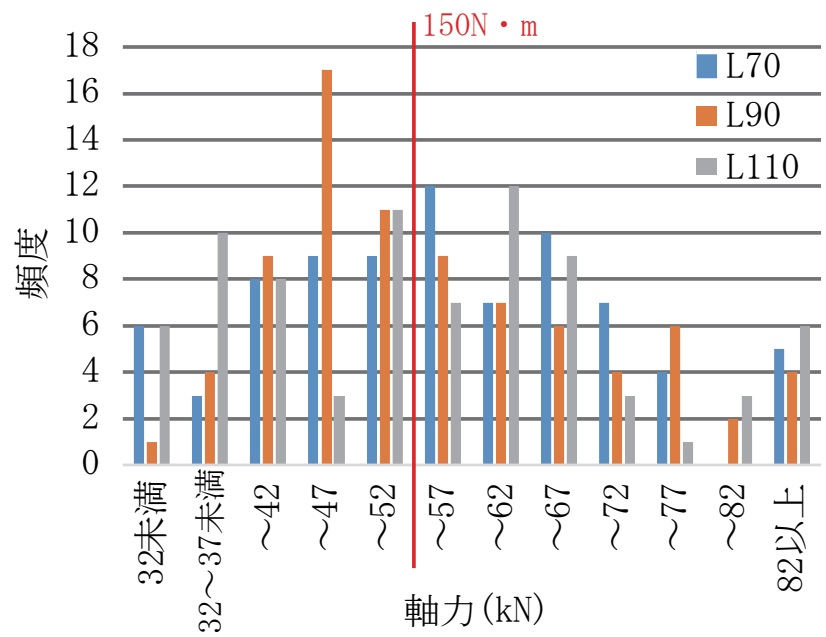

図-4 スナッグタイト試験導入軸力分布

表-5 各ボルトに導入された軸力の平均および分散

\begin{tabular}{|l|r|r|r|r|r|r|}
\hline \multirow{2}{*}{ ボルト種類 } & \multicolumn{2}{|c|}{ M22-L70 } & \multicolumn{2}{c|}{ M22-L90 } & \multicolumn{2}{c|}{ M22-L120 } \\
\cline { 2 - 6 } & 平均 & 分散 & \multicolumn{1}{c|}{ 平均 } & 分散 & 平均 & 分散 \\
\hline 軸力値 $(\mathrm{kN})$ & 55.7 & 17.7 & 54.9 & 15.3 & 54.2 & 18.7 \\
\hline
\end{tabular}

表-6 軸力 $52 \mathrm{kN}$ (トルク $150 \mathrm{Nm}$ )を上回るボルトの割合

\begin{tabular}{|l|r|r|r|r|}
\hline ボルト種類 & M22-L70 & M22-L90 & M22-L120 & 計 \\
\hline 割合 $(\%)$ & 56.3 & 47.5 & 51.9 & 51.9 \\
\hline
\end{tabular}

になっている. 3 種類のボルト軸力に対して，それぞ れの平均と分散を表-5に示す．また，150Nmを上回る 軸力となった割合を表-6に示寸．表-6における計とは， ボルト長によらず軸力が52kNを上回った割合である.

表-5および表-6より, 平均值としては $52 \mathrm{kN}$ 上回るも のの個数としては半数程度であることがわかる. 分散 值は18kN程度であるが，ここでの実験では最大と最小 の軸力の差は50kNであり, ボルト軸力は非常にばらつ いていることがわかる，なお，ボル卜長の違いによる 平均值や分散の差異は見られなかった（表-5）.

実験において，1 次締めで締付け量(トルク)の影響 は大きいと考えられる，そこで，本実験では，1 次締 めを鉄道設計標準 2)の規定值で実施することとした.

\section{3. 導入軸力試験及びリラクセーション試験方 法}

（1）試験体の使用材料および形状・法

本試験で使用した鋼材および高力ボルトの材料特性 をそれぞれ表-7および表-8 に示寸．鋼材の材料特性は 
表-7 使用鋼材の機械的性質および化学成分(軸力導入およびリラクセーション試験)

\begin{tabular}{|c|c|c|c|c|c|c|c|c|c|c|}
\hline \multirow[b]{2}{*}{ 鋼種 } & \multirow[b]{2}{*}{$\begin{array}{l}\text { 板厚 } \\
(\mathrm{mm})\end{array}$} & \multicolumn{3}{|c|}{ 機械的性質 } & \multicolumn{5}{|c|}{ 化学成分 $(\%)$} & \multirow[b]{2}{*}{ 適用場所 } \\
\hline & & $\begin{array}{l}\text { 耐力 } \\
\left(\mathrm{N} / \mathrm{mm}^{2}\right)\end{array}$ & \begin{tabular}{|l} 
張強度 \\
$\left(\mathrm{N} / \mathrm{mm}^{2}\right)$
\end{tabular} & 伸び(\%) & C & $\mathrm{Si}$ & $\mathrm{Mn}$ & $\mathrm{P}$ & $\mathrm{S}$ & \\
\hline SM490YA & 9 & 457 & 535 & 22 & 0.15 & 0.19 & 0.108 & 0.023 & 0.007 & A1の母板・連結板, B2の連結板 \\
\hline SM490YA & 12 & 482 & 537 & 22 & 0.14 & 0.18 & 0.110 & 0.016 & 0.003 & A2の連結板, B1の母板 \\
\hline SM490YB & 16 & 354 & 534 & 20 & 0.15 & 0.19 & 0.108 & 0.015 & 0.004 & B1の母板 \\
\hline SM490YB & 19 & 461 & 542 & 23 & 0.15 & 0.19 & 0.107 & 0.016 & 0.005 & $\mathrm{~A} 3, \mathrm{~B} 3 の$ 連結板 \\
\hline SM490YB & 22 & 426 & 513 & 25 & 0.15 & 0.19 & 0.108 & 0.016 & 0.004 & A2の母板 \\
\hline SM490YB & 25 & 426 & 513 & 25 & 0.15 & 0.19 & 0.108 & 0.016 & 0.004 & B2の母板 \\
\hline SM490YB & 32 & 418 & 527 & 21 & 0.15 & 0.18 & 0.107 & 0.016 & 0.006 & A3の母板 \\
\hline SM490YB & 36 & 443 & 535 & 25 & 0.15 & 0.19 & 0.112 & 0.016 & 0.005 & B3の母板 \\
\hline
\end{tabular}

表-8 使用ボルトの機械的性質とトルク係数值(軸力導入およびリラクセーション試験)

\begin{tabular}{|c|c|c|c|c|c|c|c|c|c|c|c|}
\hline \multirow{3}{*}{ ボル卜径 } & \multirow{3}{*}{$\begin{array}{c}\text { 首下長さ } \\
(\mathrm{mm})\end{array}$} & \multirow{3}{*}{$\begin{array}{c}\text { 有効 } \\
\text { 断面積 } \\
\left(\mathrm{mm}^{2}\right)\end{array}$} & \multicolumn{6}{|c|}{ ボル卜 } & \multirow{3}{*}{\begin{tabular}{|l|} 
ナット \\
製品 \\
硬さ \\
(HRC)
\end{tabular}} & \multirow{3}{*}{\begin{tabular}{|l|} 
座金 \\
製品 \\
硬さ \\
(HRC)
\end{tabular}} & \multirow{3}{*}{$\begin{array}{c}\text { トルク } \\
\text { 係数值 } \\
\text { (平均值) }\end{array}$} \\
\hline & & & \multicolumn{4}{|c|}{ 4号試験片 } & \multicolumn{2}{|c|}{ 製品 } & & & \\
\hline & & & \begin{tabular}{|l}
$\begin{array}{l}\text { 耐力 } \\
\left(\mathrm{N} / \mathrm{mm}^{2}\right)\end{array}$ \\
\end{tabular} & $\begin{array}{l}\text { 引張強度 } \\
\left(\mathrm{N} / \mathrm{mm}^{2}\right)\end{array}$ & \begin{tabular}{|l} 
伸び \\
$(\%)$
\end{tabular} & $\begin{array}{l}\text { 絞り } \\
(\%)\end{array}$ & $\begin{array}{l}\text { 引張荷重 } \\
(\mathrm{kN})\end{array}$ & $\begin{array}{l}\text { 硬さ } \\
\text { (HRC) }\end{array}$ & & & \\
\hline \multirow{3}{*}{ M22 } & 70 & \multirow{3}{*}{303} & 1025 & 1070 & 19 & 69 & 323 & 33 & 28 & 40 & 0.131 \\
\hline & 90 & & 1030 & 1071 & 19 & \begin{tabular}{l|l|}
69 &
\end{tabular} & 330 & 33 & 27 & 40 & 0.131 \\
\hline & 110 & & 1030 & 1068 & 19 & 69 & 333 & 33 & 29 & 40 & 0.131 \\
\hline \multirow{3}{*}{ M24 } & 75 & \multirow{3}{*}{353} & 1025 & 1070 & 20 & 66 & 372 & 33 & 26 & 39 & 0.136 \\
\hline & 100 & & 1033 & 1072 & 18 & 64 & 376 & 33 & 27 & 40 & 0.129 \\
\hline & 120 & & 1034 & 1070 & 20 & 66 & 377 & 33 & 27 & 40 & 0.131 \\
\hline
\end{tabular}

M22
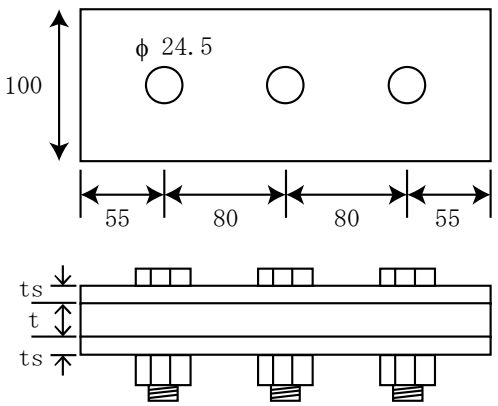

M24
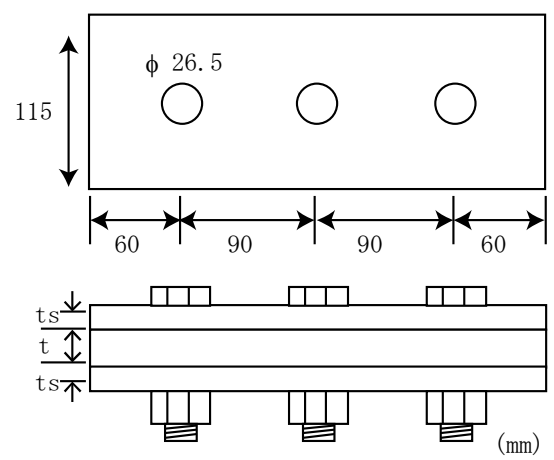

図-5＼cjkstart試験体形状(軸力導入，リラクセーション試験)

表-2 に同じである．試験体の母板および添接板には板 厚 9〜36mm の SM490Y を使用した. 使用ボルトは, 六角ボルト F10T (M22, M24)とし， ボルト長は 70〜 $120 \mathrm{~mm}$ を用いた。

図-5に試験体形状を示す。試験体は，ボルト径によ
表-9 試験体の種類

\begin{tabular}{|c|c|c|c|c|c|}
\hline \multirow{2}{*}{$\begin{array}{l}\text { 試験 } \\
\text { 体名 }\end{array}$} & \multicolumn{2}{|c|}{ 板厚(mm) } & \multirow{2}{*}{$\begin{array}{l}\text { ボルト } \\
\text { サイズ }\end{array}$} & \multicolumn{2}{|c|}{ ボルト締付け } \\
\hline & $\begin{array}{l}\text { 母板 } \\
(\mathrm{t})\end{array}$ & $\begin{array}{l}\text { 連結板 } \\
\text { (ts) }\end{array}$ & & 1次締め & 本締め \\
\hline A1-1 & \multirow{3}{*}{9} & \multirow{3}{*}{9} & \multirow{3}{*}{$\begin{array}{c}\mathrm{M} 22-\mathrm{L} 70 \\
(3.2 \mathrm{~d})\end{array}$} & \multirow{9}{*}{$150 \mathrm{~N} \cdot \mathrm{m}$} & $75^{\circ}$ \\
\hline A1-2 & & & & & $90^{\circ}$ \\
\hline A1-3 & & & & & $120^{\circ}$ \\
\hline A2-1 & \multirow{3}{*}{22} & \multirow{3}{*}{12} & \multirow{3}{*}{$\begin{array}{l}\text { M22-L90 } \\
(4.1 \mathrm{~d})\end{array}$} & & $75^{\circ}$ \\
\hline A2-2 & & & & & $90^{\circ}$ \\
\hline A2-3 & & & & & $120^{\circ}$ \\
\hline A3-1 & \multirow{3}{*}{32} & \multirow{3}{*}{19} & \multirow{3}{*}{$\begin{array}{l}\text { M22-L110 } \\
(5.0 \mathrm{~d})\end{array}$} & & $75^{\circ}$ \\
\hline A3-2 & & & & & $90^{\circ}$ \\
\hline A3-3 & & & & & $120^{\circ}$ \\
\hline $\mathrm{B} 1-1$ & \multirow{3}{*}{12} & \multirow{3}{*}{9} & \multirow{3}{*}{$\begin{array}{c}\text { M24-L75 } \\
(3.1 \mathrm{~d})\end{array}$} & \multirow{9}{*}{$200 \mathrm{~N} \cdot \mathrm{m}$} & $75^{\circ}$ \\
\hline $\mathrm{B} 1-2$ & & & & & $90^{\circ}$ \\
\hline $\mathrm{B} 1-3$ & & & & & $120^{\circ}$ \\
\hline B2-1 & \multirow{3}{*}{25} & \multirow{3}{*}{16} & \multirow{3}{*}{$\begin{array}{c}\text { M24-L100 } \\
(4.2 d)\end{array}$} & & $75^{\circ}$ \\
\hline B2-2 & & & & & $90^{\circ}$ \\
\hline $\mathrm{B} 2-3$ & & & & & $120^{\circ}$ \\
\hline B3-1 & \multirow{3}{*}{36} & \multirow{3}{*}{19} & \multirow{3}{*}{$\begin{array}{l}\text { M24-L120 } \\
(5.0 \mathrm{~d})\end{array}$} & & $75^{\circ}$ \\
\hline B3-2 & & & & & $90^{\circ}$ \\
\hline B3-3 & & & & & $120^{\circ}$ \\
\hline
\end{tabular}

り2種類を使用し，ボルト長により，適用板厚を選定 した. 1つはM22に対するものであり，図-1に示したも のと同じである。もう1つはM24に対するものである. 孔径は，各試験体ともに標準孔を用いた．ボルトピッ 
表-10 無機ジンク厚さ測定結果

\begin{tabular}{|c|c|c|c|c|}
\hline \multirow{3}{*}{$\begin{array}{c}\text { 試験体 } \\
\text { 名 }\end{array}$} & \multicolumn{4}{|c|}{ 塗装膜厚 $(\mu \mathrm{m})$} \\
\hline & \multicolumn{3}{|c|}{ ボル卜番号 } & \multirow{2}{*}{ 平均 } \\
\hline & No.1 & No. 2 & No.3 & \\
\hline $1-1$ & 88 & 87 & 77 & 84 \\
\hline $1-2$ & 87 & 82 & 85 & 85 \\
\hline $1-3$ & 95 & 87 & 92 & 91 \\
\hline $2-1$ & 85 & 89 & 98 & 91 \\
\hline $2-2$ & 94 & 83 & 80 & 86 \\
\hline $2-3$ & 89 & 94 & 95 & 93 \\
\hline A3-1 & 87 & 88 & 87 & 87 \\
\hline $3-2$ & 88 & 83 & 89 & 87 \\
\hline A3-3 & 80 & 89 & 90 & 86 \\
\hline $31-1$ & 86 & 96 & 95 & 92 \\
\hline $31-2$ & 98 & 90 & 83 & 9 \\
\hline B1-3 & 94 & 85 & 85 & 88 \\
\hline B2-1 & 94 & 87 & 94 & 92 \\
\hline $32-2$ & 97 & 84 & 87 & 8 \\
\hline B2-3 & 88 & 99 & 98 & 95 \\
\hline $33-1$ & 99 & 88 & 92 & 9. \\
\hline $33-2$ & 84 & 89 & 87 & 87 \\
\hline $33-3$ & 88 & 89 & 90 & 85 \\
\hline
\end{tabular}

チ $(P)$ や縁端距離 $(e)$ は，標準試験片10)を参考に決定した。

\section{(2) 試験体の種類}

試験体の種類を表-9 に示す。試験体のパラメータは, ボルト径，ボルト長およびナット回転角とした．M22 および M24 の両者ともに $5.0 d$ ( $d$ : ボルト径) までを 対象とし, 各径 3 ボルト長, 合わせて 6 種類のボルト を用いた。これらのボルトに対し，ナット回転角を 75 , 90, 120 の 3 角度で締付けることとした。試験体は，各 ボルト径および首下長さのパターンで 3 体製作するこ とになり, 合わせて 18 体を試験に供した.

接触面処理は，素地調整（ブラスト処理(ISO Sa2.5)) を行った後に，無機ジンクを標準膜厚 $75 \mu \mathrm{m}$ 塗布した.

\section{(3) 塗装膜厚測定}

塗装面の膜厚測定は，電磁誘導式膜厚計を用いて行 った．測定位置および測定点数は，スナッグタイト試 験の試験体と同様，図-2に示寸とおりである.

膜厚測定結果を表-10 に示している．無機ジンクの

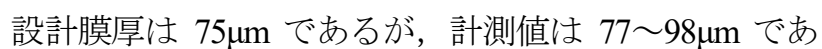
り，若干厚めであった。

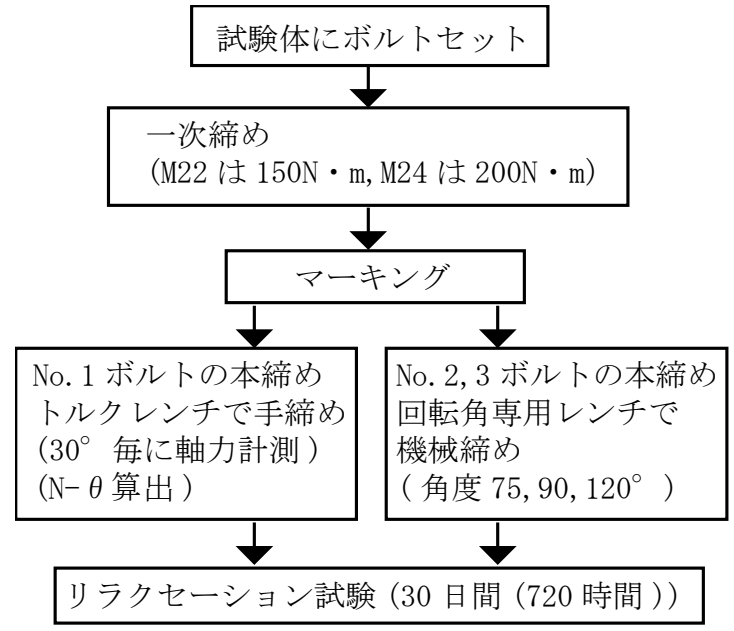

図-6 軸力導入試験のフロー

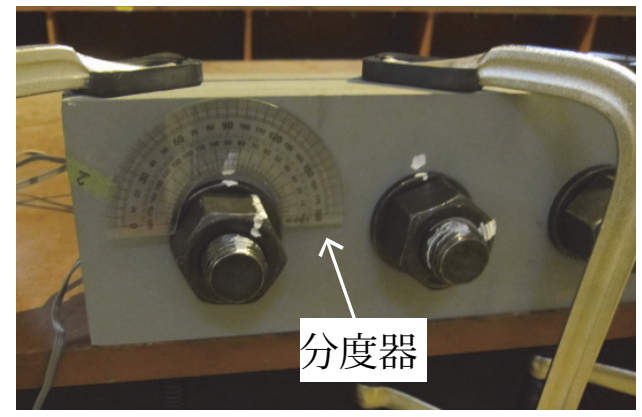

図-7 ナット回転角計測のための分度器

\section{（4） ボルト軸力の計測}

導入軸力およびリラクセーションの評価を行うため, スナッグタイト試験の試験体の際と同様に，ボルト軸 部にひずみゲージを取り付け，ボルト軸力を計測した。 6 種のボルトそれぞれに対し，荷重とひずみの関係か ら換算率を求めるキャリブレーション試験（1 種類の ボルトのつき 3 本のボルトを使用）を実施し，ひずみ からボルト軸力を算出するための換算率を求めた.

\section{(5) ボルトの締付け作業}

導入軸力試験において用いたナット回転法によるボ ルトの締付け手順を図-6 に示す．作業は，一次締めお よびマーキング後，本締めを行った１ 1 試験体でボル 卜は 3 本あるが，本締め作業では，その内 1 本(No.1) は，トルクレンチを用いて手締めで行い，残り 2 本 (No.2,3)は，設定した回転角に締付けるナット回転角専 用レンチを用いた機械締めとした。手締めは図-7 に 示すように分度器を中心がボルト中心に一致するよう に削り取り，あてながら回転角の計測を行った。 
表-11 軸力導入試験およびリラクセーション試験の計測結果の一覧

\begin{tabular}{|c|c|c|c|c|c|c|c|c|c|c|c|c|c|c|c|c|c|c|c|c|c|}
\hline \multirow{4}{*}{\multicolumn{2}{|c|}{\begin{tabular}{|l} 
試験体名 \\
\end{tabular}}} & \multirow{4}{*}{$\begin{array}{l}\text { ボルト } \\
\text { サイズ }\end{array}$} & \multicolumn{11}{|c|}{ 初期導入時の軸力 $(\mathrm{kN})$} & \multicolumn{8}{|c|}{ リラクセーション(720h)後の軸力 $(\mathrm{kN})$} \\
\hline & & & \multirow{3}{*}{$\begin{array}{c}\text { 回転量 } \\
\left({ }^{\circ}\right)\end{array}$} & \multirow{2}{*}{\multicolumn{6}{|c|}{$\begin{array}{c}\text { 手締め(トルクレンチ) } \\
\text { No.1 ボルト }\end{array}$}} & \multicolumn{2}{|c|}{ 機械締め } & \multirow{3}{*}{ 平均值 } & \multirow{3}{*}{\begin{tabular}{|c} 
設計値 \\
比率 \\
$(\%)$
\end{tabular}} & \multicolumn{2}{|c|}{ 手締め } & \multicolumn{4}{|c|}{ 機械締め } & \multirow{3}{*}{ 平均值 } & \multirow{3}{*}{\begin{tabular}{|c|} 
設計值比 \\
率(\%)
\end{tabular}} \\
\hline & & & & & & & & & & \multirow{2}{*}{\begin{tabular}{|c|} 
No.2 \\
ボルト
\end{tabular}} & \multirow{2}{*}{\begin{tabular}{|c} 
No.3 \\
ボルト
\end{tabular}} & & & \multirow{2}{*}{\begin{tabular}{|c|} 
No.1 \\
ボルト
\end{tabular}} & \multirow{2}{*}{ 割合 $(\%)$} & \multirow{2}{*}{\begin{tabular}{|r} 
No.2 \\
ボルト
\end{tabular}} & \multirow{2}{*}{ 割合 $(\%)$} & \multirow{2}{*}{\begin{tabular}{|c|} 
No.3 \\
ボルト
\end{tabular}} & \multirow{2}{*}{ 割合 $(\%)$} & & \\
\hline & & & & $0^{\circ}$ & $30^{\circ}$ & $60^{\circ}$ & $75^{\circ}$ & $90^{\circ}$ & $120^{\circ}$ & & & & & & & & & & & & \\
\hline \multirow{9}{*}{ M22 } & A1-1 & \multirow{3}{*}{$\begin{array}{c}\mathrm{M} 22 \times 70 \\
3.2 \mathrm{~d}\end{array}$} & 75 & 43.89 & 117.8 & 183.0 & 241.3 & & & 256.7 & 248.0 & 248.7 & 121.3 & 218.3 & 106.5 & - & & 222.4 & 108.5 & 220.4 & 107.5 \\
\hline & 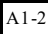 & & 90 & 50.13 & 143.6 & 224.0 & & 282.5 & & 253.3 & 243.2 & 259.7 & 126.7 & 259.5 & 126.6 & 204.5 & 99.8 & 218.5 & 106.6 & 227.5 & 111.0 \\
\hline & A1-3 & & 120 & 60.63 & 154.9 & 225.6 & & 282.3 & 324.0 & 295.1 & 293.2 & 304.1 & 148.3 & 306.2 & 149.4 & 280.6 & 136.9 & 265.7 & 129.6 & 284.2 & 138.6 \\
\hline & A2-1 & \multirow{3}{*}{$\begin{array}{c}\mathrm{M} 22 \times 90 \\
4.1 \mathrm{~d}\end{array}$} & 75 & 68.74 & 140.9 & 221.7 & 258.4 & & & 231.5 & 239.2 & 243.0 & 118.5 & 236.7 & 115.5 & 209.8 & 102.3 & 219.2 & 106.9 & 221.9 & 108.2 \\
\hline & \begin{tabular}{|l|} 
A2-2 \\
\end{tabular} & & 90 & 67.85 & 130.1 & 211.6 & & 277.4 & & 267.2 & 285.8 & 276.8 & 135.0 & 250.8 & 122.3 & 240.5 & 117.3 & 260.8 & 127.2 & 250.7 & 122.3 \\
\hline & A2-3 & & 120 & 54.63 & 115.3 & 197.6 & & 263.5 & 297.0 & - & 291.6 & 294.3 & 143.5 & 278.6 & 135.9 & - & - & 269.8 & 131.6 & 274.2 & 133.8 \\
\hline & A3-1 & \multirow{3}{*}{$\begin{array}{c}\text { M } 22 \times 110 \\
5.0 \mathrm{~d}\end{array}$} & 75 & 52.71 & 101.5 & 160.8 & 188.9 & & & 209.9 & 219.4 & 206.0 & 100.5 & 167.2 & 81.6 & 195.4 & 95.3 & 207.3 & 101.1 & 190.0 & 92.7 \\
\hline & A3-2 & & 90 & 41.64 & 104.1 & 185.4 & & 253.8 & & 219.5 & 229.7 & 234.3 & 114.3 & 239.3 & 116.7 & 183.4 & 89.5 & 216.8 & 105.7 & 213.2 & 104.0 \\
\hline & A3-3 & & 120 & 51.92 & 104.0 & 170.6 & & 226.9 & 268.0 & 272.7 & - & 270.4 & 131.9 & 251.8 & 122.8 & 253.4 & 123.6 & & - & 252.6 & 123.2 \\
\hline
\end{tabular}

\begin{tabular}{|c|c|c|c|c|c|c|c|c|c|c|c|c|c|c|c|c|c|c|c|c|c|}
\hline \multirow{4}{*}{\multicolumn{2}{|c|}{ 圾験体名 }} & \multirow{4}{*}{$\begin{array}{l}\text { ボルト } \\
\text { サイズ }\end{array}$} & \multicolumn{11}{|c|}{ 初期導入軸力 $(\mathrm{kN})$} & \multicolumn{8}{|c|}{ リラクセーション (720h)後の軸力 $(\mathrm{kN})$} \\
\hline & & & \multirow{3}{*}{$\begin{array}{c}\text { 回転量 } \\
\left({ }^{\circ}\right)\end{array}$} & \multirow{2}{*}{\multicolumn{6}{|c|}{$\begin{array}{c}\text { 手締め(トルクレンチ) } \\
\text { No.1ボルト }\end{array}$}} & \multicolumn{2}{|c|}{ 機械締め } & \multirow{3}{*}{ 平均値 } & \multirow{3}{*}{\begin{tabular}{|c} 
設計値 \\
比率 \\
$(\%)$
\end{tabular}} & \multicolumn{2}{|c|}{ 手締め } & \multicolumn{4}{|c|}{ 機械締め } & \multirow{3}{*}{ 平均値 } & \multirow{3}{*}{$\begin{array}{l}\text { 設計値 } \\
\text { 比率 }(\%)\end{array}$} \\
\hline & & & & & & & & & & \multirow{2}{*}{$\begin{array}{c}\text { No.2 } \\
\text { ボルト }\end{array}$} & \multirow{2}{*}{\begin{tabular}{|c|} 
No.3 \\
ボルト
\end{tabular}} & & & \multirow{2}{*}{\begin{tabular}{|c|} 
No.1 \\
ボルト
\end{tabular}} & \multirow{2}{*}{ 割合 $(\%)$} & \multirow{2}{*}{\begin{tabular}{|c|} 
No.2 \\
ボルト
\end{tabular}} & \multirow{2}{*}{ 割合 $(\%)$} & \multirow{2}{*}{\begin{tabular}{|c|} 
No.3 \\
ボルト
\end{tabular}} & \multirow{2}{*}{ 割合 $(\%)$} & & \\
\hline & & & & $0^{\circ}$ & $30^{\circ}$ & $60^{\circ}$ & $75^{\circ}$ & $90^{\circ}$ & $120^{\circ}$ & & & & & & & & & & & & \\
\hline \multirow{9}{*}{ M24 } & B1-1 & \multirow{3}{*}{$\begin{array}{l}\text { M24x75 } \\
3.1 \mathrm{~d}\end{array}$} & 75 & 36.38 & 140.8 & 226.5 & 291.7 & & & 307.5 & 297.1 & 298.8 & 125.5 & 271.6 & 114.1 & 277.2 & 116.5 & 262.7 & 110.4 & 270.5 & 113.7 \\
\hline & B1-2 & & 90 & 33.81 & 139.5 & 259.3 & & 327.6 & & & 325.6 & 326.6 & 137.2 & 301.9 & 126.8 & - & - & 302.0 & 126.9 & 302.0 & 126.9 \\
\hline & B1-3 & & 120 & 40.14 & 131.0 & 244.6 & & 326.7 & 349.2 & 321.1 & 305.2 & 325.2 & 136.6 & 324.8 & 136.5 & 299.5 & 125.9 & 282.4 & 118.6 & 302.2 & 127.0 \\
\hline & B2-1 & \multirow{3}{*}{$\begin{array}{c}\mathrm{M} 24 \times 100 \\
4.2 \mathrm{~d}\end{array}$} & 75 & 38.02 & 119.0 & 235.2 & 294.8 & & & 288.3 & 284.0 & 289.0 & 121.4 & 267.7 & 112.5 & 263.3 & \begin{tabular}{ll|}
110.6 \\
\end{tabular} & 262.3 & 110.2 & 264.4 & 111.1 \\
\hline & B2-2 & & 90 & 40.69 & 135.3 & 244.8 & & 329.1 & & 326.0 & 326.5 & 327.2 & 137.5 & 302.5 & 127.1 & 300.3 & 126.2 & 299.7 & 125.9 & 300.8 & 126.4 \\
\hline & B2-3 & & 120 & 35.36 & 119.6 & 242.8 & & 336.2 & 348.5 & 326.8 & 331.0 & 335.4 & 140.9 & 320.1 & 134.5 & - & - & 305.5 & 128.4 & 312.8 & 131.4 \\
\hline & B3-1 & \multirow{3}{*}{$\begin{array}{c}\text { M } 24 \times 120 \\
5.0 \mathrm{~d}\end{array}$} & 75 & 40.84 & 112.6 & 223.8 & 279.4 & & & 264.8 & 276.0 & 273.4 & 114.9 & 256.6 & $\begin{array}{ll}107.8 \\
\end{array}$ & - & - & - & - & 256.6 & 107.8 \\
\hline & B3-2 & & 90 & 41.12 & 112.8 & 202.7 & & 289.0 & & 303.9 & 305.9 & 299.6 & 125.9 & 267.9 & 112.5 & 281.7 & 118.4 & 278.5 & 117.0 & 276.0 & 116.0 \\
\hline & \begin{tabular}{|l|} 
B3-3 \\
\end{tabular} & & 120 & 44.30 & 131.4 & 228.4 & & 324.5 & 337.3 & 316.5 & 315.9 & 323.2 & 135.8 & 312.5 & 131.3 & 293.1 & 123.1 & 295.4 & 124.1 & 300.3 & 126.2 \\
\hline
\end{tabular}

\section{(6) 導入軸力試験方法}

導入軸力試験では, 各試験体の No.1 ボルトについ

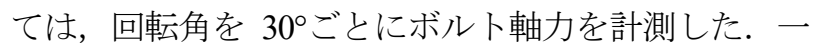
方, No.2,3 ボルトでは, 表-9 に示す所定の角度の軸力 のみ計測した. これら両者の結果より, 導入軸力と回 転角の関係を定量的に評価することとした.

軸力の初期を表す時刻としては，個々のボルトの本 締め直後のひずみ值が最高となり, リラクセーション が始まる時点とした. 手締めによるボルトを 30 ごと に締める際もひずみが一旦安定し，下がり始めたと判 断できる時点でひずみを軸力に換算した.データロガ 一のひずタ計測間隔は 10 秒間で，ボルト本締め後あ るいは 30。締付け後には声で合図を送ったが，初期時 刻としては, 締付け直後から 30 秒以内におさまって いた. 1 本目のボルトを締付けたのちに, 次のボルト の締付けを同様にして行い，さらにその次のボルトを 締付けた. 1 本目のボルトを締付けたのちにはリラク セーションによりひずみの值は時間とともに減少する が 2 本目のボルトを締付けることによって変化の度合 いが大きく変わることはなかった.つまり，1 本のボ ルトが隣のボルトの軸力に与える影響はそれほど顕著 ではないと考えられる。

一連の締付け作業終了後は 1 時間に 1 回の軸力測定 を行った. 3 日後には 1 日 1 回計測している.
表-12 残存軸力の割合

\begin{tabular}{|c|c|c|c|c|c|c|c|}
\hline & \multicolumn{6}{|c|}{ 軸力残存率 $(\%)$} \\
\hline & & \multicolumn{3}{|c|}{ M22 } & \multicolumn{3}{|c|}{ M24 } \\
\hline & & \begin{tabular}{|l|} 
L70 \\
$(3.2 \mathrm{~d})$
\end{tabular} & $\begin{array}{l}\text { L90 } \\
(4.1 d)\end{array}$ & $\begin{array}{l}\mathrm{L} 110 \\
(5.0 \mathrm{~d})\end{array}$ & $\begin{array}{l}\mathrm{L} 75 \\
\text { (3.1d) }\end{array}$ & $\begin{array}{l}\text { L100 } \\
(4.2 \mathrm{~d})\end{array}$ & $\begin{array}{l}\mathrm{L} 120 \\
(5.0 \mathrm{~d})\end{array}$ \\
\hline 回 & $75^{\circ}$ & 90.06 & 91.29 & 92.05 & 90.57 & 91.49 & 91.85 \\
\hline 転 & $90^{\circ}$ & 87.48 & 90.55 & 90.74 & 92.46 & 91.94 & 92.14 \\
\hline & $120^{\circ}$ & 93.41 & 93.18 & 93.44 & 92.93 & 92.07 & 92.92 \\
\hline \multirow{2}{*}{\multicolumn{2}{|c|}{ 平均值 }} & 90.32 & 91.67 & 92.07 & 91.99 & 91.84 & 92.30 \\
\hline & & \multicolumn{3}{|c|}{91.35} & \multicolumn{3}{|c|}{92.04} \\
\hline
\end{tabular}

\section{(7) リラクセーション試験方法}

リラクセーション試験は，表-9 で示した 18 ケース であり，合わせて 54 本のボルトとし，計測期間は 720 時間(30日)とした。

\section{4. 導入軸力試験及びリラクセーション試験結 果}

\section{(1) 導入軸力試験の計測結果}

導入軸力試験の結果を表-11 に示す．表-11 において たとえば A2-3 試験体の No.2 ボルトの軸力が横線「-」 になっているものがあるが，これらはひずみゲージな どの不具合で計測ができなかったものである.

表-11 の初期導入時の軸力で, No.1 から 3 の平均值 の闌を見ると, M22 およびM24において, ボルト長 


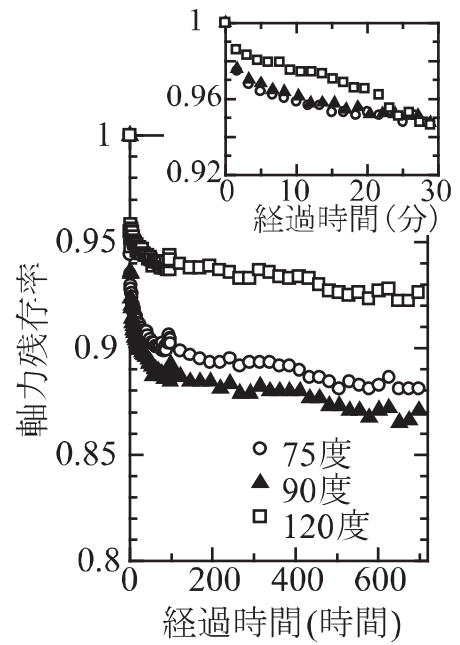

(a) M22-L70

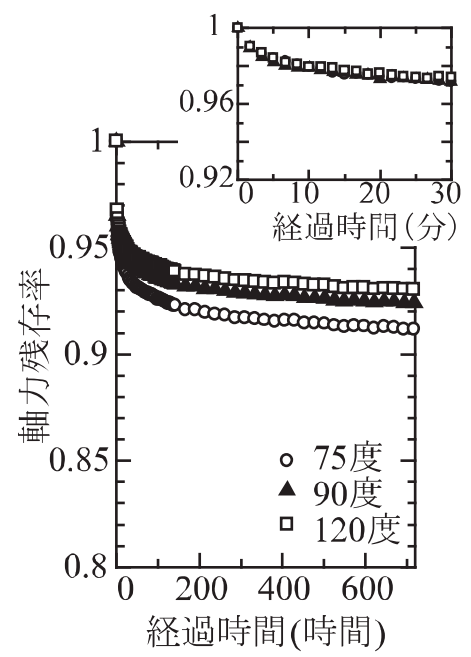

(d) M24-L75

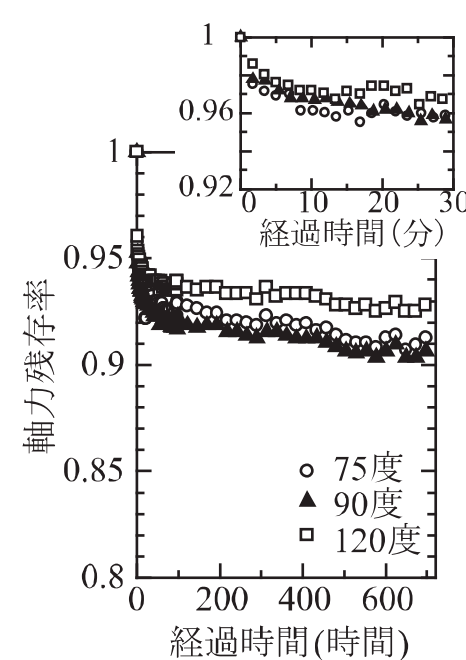

(b) M22-L90

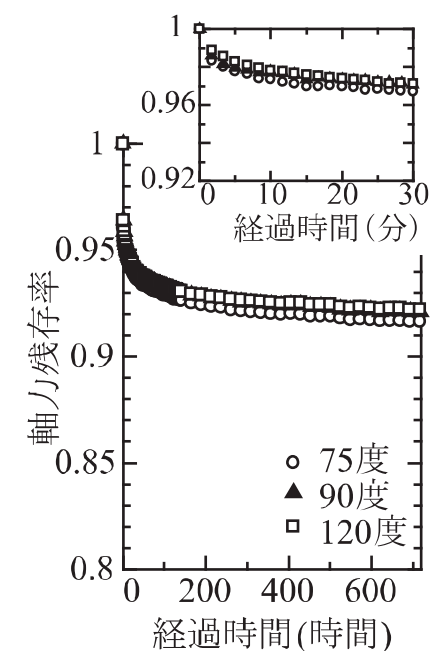

(e) M24-L100

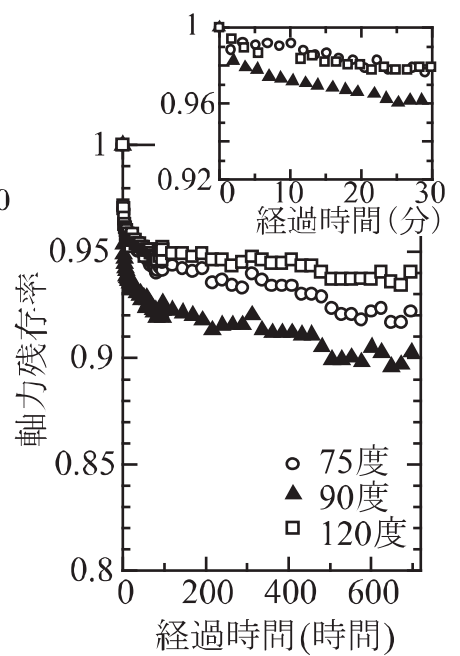

(c) M22-L110

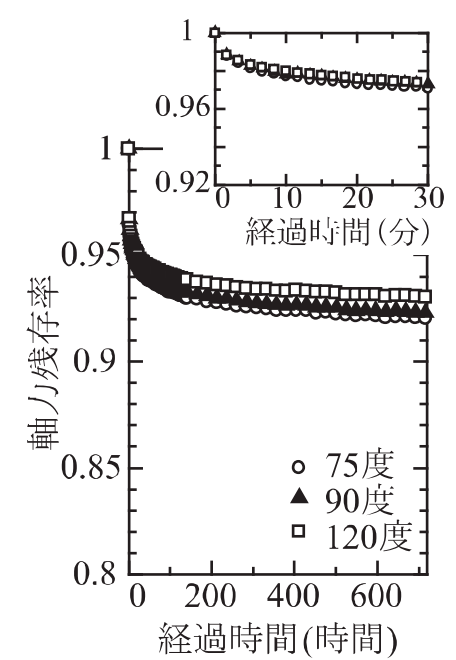

(f) M24-L120

図-8 リラクセーション試験による軸力残存率の低下

が長くなるにつれて導入軸力が低くなる傾向およびナ ット回転角が大きくなるにつれて，導入軸力が高くな る傾向が見られる.

設計值比率では M22-L110(長さ $110 \mathrm{~mm}$ のボルトであ ることを示している)では，100～130\%程度であったが， 他の試験体では，120～140\%の範囲にあるものが多い. ナット回転角と導入軸力の関係を見ると, 回転角 $75^{\circ}$ で導入軸力は設計值に比較して $100 \sim 125 \% ， 90^{\circ}$ で 115 〜135\%，120で 135〜150\%程度となっている。

\section{(2) リラクセーション試験による軸力残存率の結果}

表-12 において, リラクセーション後の軸力を数值 で示している. 図-8に，リラクセーションによるひ ずみの経時変化を示す．図-8 の縦軸は初期のひずみ 值により無次元化したものである.これらの曲線は試

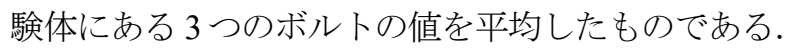

図-8(a)〜(c)は M22，図-8(d)〜(f)は M24 の結果であ
る. M22-L75 および-L110 の一部で残存率が 90\%を若 干下回る程度に落ち込んでいる試験体，あるいは， 90\%程度にまで低下している試験体が見られる。しか しながら，他の大部分のボルトにおいては，軸力低下 は 92〜94\%程度におさまっている. M22-L75 および M22-L110 の一部で残存率が 90\%を若干下回る程度に 落ち込んでいる試験体，あるいは，90\%程度にまで低 下している試験体が見られる. しかしながら, 他の大 部分のボルトにおいては, 軸力低下は 92〜94\%程度に おさまっている.

リラクセーションは締付け直後が著しいといわれて いる ${ }^{8)}$. 初期の 30 分間の軸力の推移を各図とともに 拡大して示しているが，いずれの試験体においても， 94〜98\%にまで低下していることがわかる．その後も 軸力は低下し続け，200 時間ほどが経過すると，軸力 の低下はさほど見られなくなる場合が多かった。

ナット回転角との関係を見ると, 多くの試験体にお 

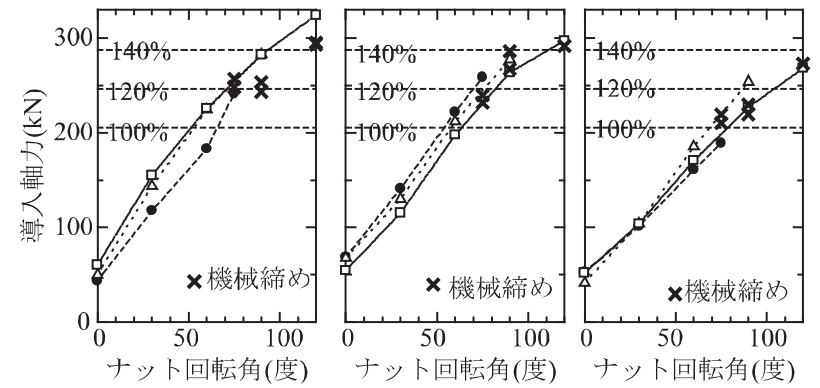

(a) M22-L 70

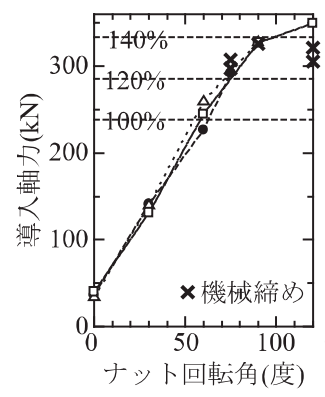

(b) M22-L90

(c) M22-L110

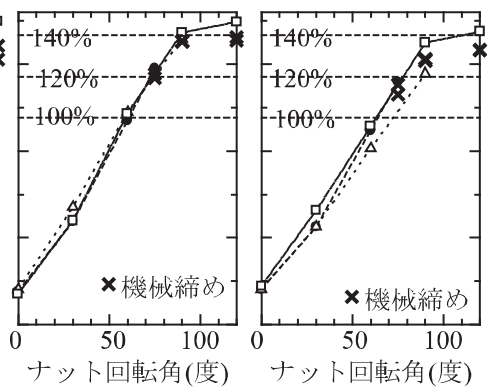

(d) M24-L75

(e) M24-L100

(f) M24-L120

図-9 ナット回転量とボルト導入軸力

いて，回転角が大きいほうが，軸力残存率が高い傾向 が見られた。

リラクセーション試験において，720 時間後の軸力 残存率の数值を表にしたものが表-12 であるが，既往 の研究において ${ }^{13)}$ ，著者の一人が同様に無機ジンク のリラクセーション試験を行ったが，軸力残存率はお おむね 90\%程度であり, 既往の研究と同様の傾向を 示した.

\section{(3) ナット回転量の考察}

図-9に，軸力導入試験時のナット回転量と導入軸力 の関係を示す．図-9(a)〜(c)は M22，(d)〜(f)は M24の 場合である。

図-9(a)〜(b)の M22 において，L70 および L90 では， ナット回転量が $60^{\circ}$ ではおおむね設計軸力が導入され ていることがわかる．また，ナット回転量が $75^{\circ}$ にな ると設計軸力の $120 \%$ 導入されているといえる.し かし，図-9(c)に示すように，L110になると，ナット回 転量が $75^{\circ}$ で設計軸力とほぼ同じ軸力が導入され，90 で120\%になる結果となった。

ナット回転量が 120 になると，L70 および L 90 にお いて，ボルト軸力は設計軸力の $140 \%$ になる。図-9(b) の L90 においては，ナット回転量が $90^{\circ}$ を超えると導 入軸力との関係が線形ではなくなっている.

図-9(d)〜(f)の M24 においては，L75，L100 だけでな く, L120 の場合でもナット回転量 $60^{\circ}$ において設計軸

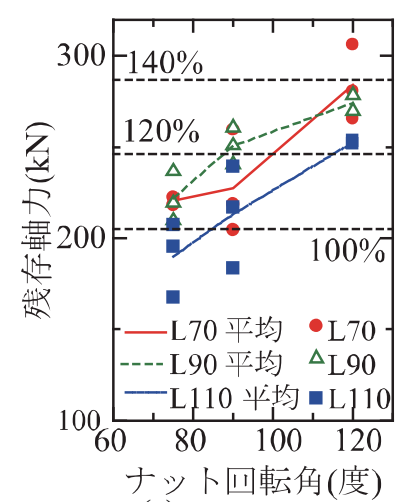

(a) M22

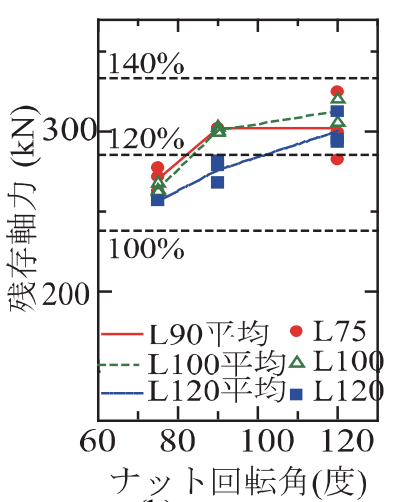

(b) M24
図-10 720 時間後のボルト軸力とナット回転角

表-13 提案するナット回転量

\begin{tabular}{|l|l|l|l|l|}
\hline \multirow{2}{*}{ ボルト締め付け } & \multicolumn{4}{|c|}{ ボルト径 } \\
\cline { 2 - 5 } & \multicolumn{2}{|c|}{$\mathrm{M} 22$} & \multicolumn{2}{c|}{$\mathrm{M} 24$} \\
\hline ボルト長 & $\leqq 4.1 d$ & $\leqq 5.0 d$ & $\leqq 4.2 d$ & $\leqq 5.0 d$ \\
\hline $\begin{array}{l}\text { 一次締め } \\
\text { (トルク法) }\end{array}$ & $150 \mathrm{Nm}$ & $150 \mathrm{Nm}$ & $200 \mathrm{Nm}$ & $200 \mathrm{Nm}$ \\
\hline $\begin{array}{l}\text { 本締め } \\
\text { (ナット回転法) }\end{array}$ & 90 度 & 105 度 & 85 度 & 90 度 \\
\hline
\end{tabular}

$d:$ ボルト径

力と同等の軸力が導入されていること, およびナット 回転量 $75^{\circ}$ で $120 \%$ が導入されていることがわかる.

M24 では寸べてのボルト長において，ナット回転量が 90を超えると，それまでの導入軸力-ナット回転角関 係から傾きが減少し, 非線形領域に入っていることが わかる。

以上の結果から，実施工でのナット回転法の適用に 向けたナット回転量の提案を行う。ここでのボルト締 付けは締付け精度が高い, ナット回転角専用レンチを 使用することを前提としている．適切なナット回転量 とは，ボルトねじ部が降伏域(非線形性が生じない)に 入らないこと, およびリラクセーション後も設計ボル 卜軸力を満足することの条件を満たす回転量 4),5) とな る。なお，トルク法では，設計ボルト軸力の $110 \%$ の 軸力となるように締付け，その締付けトルクの規定上

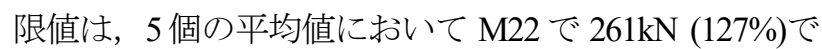
ある. 実施工では，個々のボルトでは 200～260kN で 締付けられ，その平均值は $231 \mathrm{kN}(112 \%)$ である ${ }^{13)}$.

図-10 にリラクセーション後, つまり 720 時間後の ボルト軸力と締付け時のナット回転量の関係を示す.

図-10(a)の M22 においては，L70および L90では 90が 上記で示した軸力範囲に入っているといえる. L110 では $90^{\circ}$ においては設計軸力とほぼ同じ值となってし まうことからそれより若干大きい $105^{\circ}$ が，L70 と同等 
の軸力であると考えられる。

表-11の M24においては，M22より同じ角度でも軸 力が高く，L75 および L100 において 90。では 126\%を 上回る.よって $90^{\circ}$ よりも若干小さい $85^{\circ}$ がよいと考え られる. $85^{\circ}$ における近似線では $120 \%$ となる角度とな る.ただし，L120 においては，回転量 90。おいて軸 力は 116\%となっているので，90゚でよいと判断した.

既往の研究で遅れ破壊に関するものとして池田・畑 中14)のものがある. 池田らはF10T-M22相当のボルトを 用いて海上環境などで暴露試験を20年間続けている.

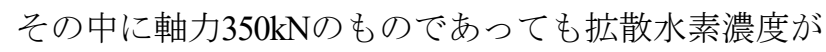
$0.6 \mathrm{ppm}$ 程度で遅れ破壊の可能性が生じてくる1.0ppmに 対して余裕があることを示している．他の文献15),16)で も遅れ破壊は報告されていない。西川ら3)も腐食環境 への配慮が必要と述べつつも，鋼材品質の向上もあり， 遅れ破壊は起こりにくいのではないかと述べている.

提案されたナット回転量をまとめると表-13のよう になる，表-13は平均值での提案であるが，1度単位の 規定は現実的ではなく，5度程度の誤差を見込んでの 提案を行っている. また，ボルト継手としてはボルト 軸力の平均值で評価することになるので，平均值の議 論で妥当であると思われる. なお，施工に関しては， 従来と同様に適切な施工管理を行い, 特に一次締めの 軸力管理には十分な配慮が必要であると考えている. 上記の既往の研究結果もふまえて，提案する方法でボ ルトを締付けたとしても遅れ破壊の可能性は少ないと 考える.なお， $5.0 d$ を越える場合は，試験を行い，回 転量を設定する必要があると考えられる。

\section{5. すべり耐力試験}

\section{（1）試験体の使用材料および形状 - 寸法}

本試験で使用した鋼材および高力ボルトは，2，3 章 と同じ表-7，表-8で示した材料を使用した。

試験体形状を図-11 に示す.ボルト径による 2 種類 を使用し，ボルト長により適用板厚を選定した。また， 孔径は，各試験体ともに標準孔を用い，その他の寸法 については，標準試験片 12)の寸法とした。 母板あるい は連結板の降伏荷重に対するす心゙り荷重の比 $(\beta$ 值) 0.6〜0.9 であり, すべり先行で限界状態となる条件と なっている。なお，試験体は固定側とすべり側を設定 し，固定側については 3 本のボルトを配置し，す心゙ら せないよう配慮した。

\section{（2）試験体の種類および接触面の表面処理}

試験体の種類を表-14 に示す．試験体の種類は，2，
M22
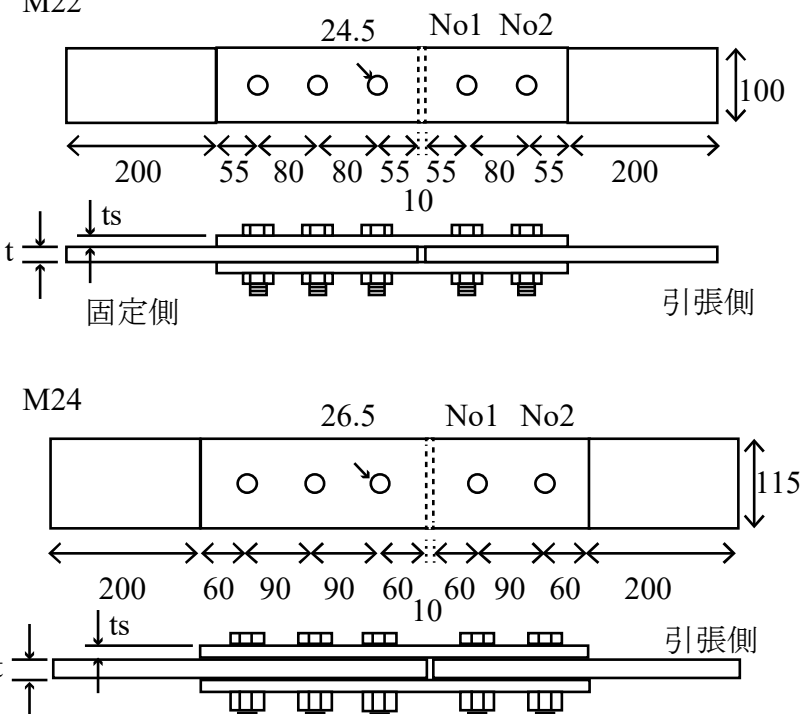

図-11 すべり耐力試験の試験体

表-14 すべり耐力試験の種類

\begin{tabular}{|c|c|c|c|c|c|}
\hline \multirow[b]{2}{*}{$\begin{array}{l}\text { 試験 } \\
\text { 体名 }\end{array}$} & \multicolumn{2}{|c|}{ 板厚(mm) } & \multirow{2}{*}{$\begin{array}{l}\text { ボルト } \\
\text { サイズ }\end{array}$} & \multirow[b]{2}{*}{ 1次締め } & \multirow[b]{2}{*}{$\begin{array}{l}\text { 本締女 } \\
\text { 回転角 }\end{array}$} \\
\hline & $\begin{array}{l}\text { 母板 } \\
(\mathrm{t})\end{array}$ & 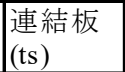 & & & \\
\hline $\mathrm{Cl}$ & 22 & 12 & M22-L90(4.1 $d)$ & \multirow{2}{*}{$150 \mathrm{~N} \cdot \mathrm{m}$} & $90^{\circ}$ \\
\hline $\mathrm{C} 2$ & 32 & 19 & M22-L110(5.0d) & & $105^{\circ}$ \\
\hline D1 & 25 & 16 & M24-L100(4.2d) & \multirow{2}{*}{$200 \mathrm{~N} \cdot \mathrm{m}$} & $85^{\circ}$ \\
\hline D2 & 36 & 19 & M24-L120(5.0d) & & $90^{\circ}$ \\
\hline
\end{tabular}

表-15 無機ジンク厚さ測定結果

\begin{tabular}{|l|r|r|r|}
\hline 試験 & \multicolumn{2}{|c|}{ 膜厚 $(\mu \mathrm{m})$} & \multicolumn{1}{c|}{ 平均値(母板と } \\
\cline { 2 - 3 } 名板 & 連結板 & 連結板 $)$ \\
\hline $\mathrm{C} 1-1$ & 87 & 87 & 87 \\
\hline $\mathrm{C} 1-2$ & 91 & 97 & 94 \\
\hline $\mathrm{C} 1-3$ & 86 & 88 & 87 \\
\hline $\mathrm{C} 2-1$ & 92 & 84 & 91 \\
\hline $\mathrm{C} 2-2$ & 91 & 91 & 85 \\
\hline $\mathrm{C} 2-3$ & 85 & 85 & 92 \\
\hline $\mathrm{D} 1-1$ & 85 & 99 & 90 \\
\hline $\mathrm{D} 1-2$ & 83 & 96 & 88 \\
\hline $\mathrm{D} 1-3$ & 85 & 90 & 86 \\
\hline $\mathrm{D} 2-1$ & 87 & 85 & 96 \\
\hline $\mathrm{D} 2-2$ & 91 & 100 & 93 \\
\hline $\mathrm{D} 2-3$ & 100 & 86 & \\
\hline
\end{tabular}

3 章を参考に, ボルト径およびボルト長を変えた 4 種 類とし，試験体は，各種類で 3 体製作し，合わせて 12 体を試験に供した。

塗装作業, 膜厚計測についても，2，3 章と同様とし た.また，これらの作業は，2，3 章の試験体と同時に 行った. 膜厚計測結果を表-15に示す.

(3) ボルトの締付けおよびひずみ計測

一次締めおよび本締めは，4章で提案した表-13に 
表-16 すべり耐力試験結果およびすべり係数

\begin{tabular}{|c|c|c|c|c|c|c|c|c|c|c|c|c|c|c|c|c|}
\hline \multirow{3}{*}{$\begin{array}{l}\text { 試 } \\
\text { 験 } \\
\text { 体 }\end{array}$} & \multicolumn{5}{|c|}{ 締付け直後 $N_{a}$} & \multicolumn{5}{|c|}{ すべり試験直前 $N_{b}$} & \multirow{3}{*}{$\begin{array}{c}\text { 軸力残 } \\
\text { 存率 }\end{array}$} & \multirow{3}{*}{$\begin{array}{l}\text { 残存率 } \\
\text { 平均 }\end{array}$} & \multirow{3}{*}{$\begin{array}{c}\text { す心゙り } \\
\text { 荷重 } \\
(\mathrm{kN}) \\
\end{array}$} & \multirow{3}{*}{$\begin{array}{l}\text { 寸べ } \\
\text { り音 }\end{array}$} & \multicolumn{2}{|c|}{ すべり係数 } \\
\hline & \multicolumn{2}{|c|}{ 軸力 $(\mathrm{kN})$} & \multirow{2}{*}{ 平均 } & \multirow{2}{*}{\begin{tabular}{c|}
$\begin{array}{c}\text { 設計値 } \\
\text { 比率 }\end{array}$ \\
\end{tabular}} & \multirow{2}{*}{$\begin{array}{l}\text { 設計比 } \\
\text { 率平均 }\end{array}$} & \multicolumn{2}{|c|}{ 軸力 $(\mathrm{kN})$} & \multirow{2}{*}{\begin{tabular}{|l} 
平均軸 \\
力 $(\mathrm{kN})$
\end{tabular}} & \multirow{2}{*}{\begin{tabular}{l|} 
設計 \\
比率
\end{tabular}} & \multirow{2}{*}{\begin{tabular}{|l|}
\begin{tabular}{|l|} 
\\
率平計均
\end{tabular} \\
\end{tabular}} & & & & & \multirow{2}{*}{$\begin{array}{l}\mu_{a} \text { (実軸 } \\
\text { 力による) }\end{array}$} & \multirow{2}{*}{\begin{tabular}{|c|}
$\mu_{b}($ 設計軸 \\
力による $)$
\end{tabular}} \\
\hline & No.1 & \begin{tabular}{|l|} 
No. \\
\end{tabular} & & & & No.1 & No. 2 & & & & & & & & & \\
\hline C1-1 & 260.0 & 244.8 & 252.4 & 123.1 & \multirow{3}{*}{119.4} & 235.5 & 221.0 & 228.3 & 111.4 & \multirow{3}{*}{108.1} & 90.61 & \multirow{3}{*}{91.03} & 513.6 & あり & 0.562 & 0.626 \\
\hline C1-2 & 236.2 & 253.9 & 245.1 & 119.5 & & & & & & & & & 433.6 & あり & & 0.529 \\
\hline $\mathrm{Cl} 1-3$ & 245.2 & 228.2 & 236.7 & 115.5 & & 224.2 & 205.4 & 214.8 & 104.8 & & 91.46 & & 410.8 & あり & 0.478 & 0.501 \\
\hline C2-1 & 262.6 & - & 262.6 & 128.1 & \multirow{3}{*}{123.2} & 239.6 & - & 239.6 & 116.9 & \multirow{3}{*}{113.3} & 91.23 & \multirow{3}{*}{91.78} & 539.2 & あり & 0.563 & 0.658 \\
\hline \begin{tabular}{|l|}
$\mathrm{C} 2-2$ \\
\end{tabular} & 255.0 & 244.1 & 249.5 & 121.7 & & 233.1 & 226.5 & 229.8 & 112.1 & & 91.41 & & 498.8 & あり & 0.543 & 0.608 \\
\hline \begin{tabular}{|l|}
$\mathrm{C} 2-3$ \\
\end{tabular} & 239.9 & 251.2 & 245.5 & 119.8 & & 222.4 & 232.2 & 227.3 & 110.9 & & 92.70 & & 576.4 & あり & 0.634 & 0.703 \\
\hline D1-1 & 325.0 & 304.1 & 314.6 & 132.2 & \multirow{3}{*}{125.3} & 287.4 & 276.3 & 281.9 & 118.4 & \multirow{3}{*}{113.4} & 88.42 & \multirow{3}{*}{89.79} & 561.2 & あり & 0.498 & 0.589 \\
\hline D1-2 & L & 290.5 & 290.5 & 122.1 & & - & 263.1 & 263.1 & 110.6 & & & & 565.4 & あり & 0.537 & 0.594 \\
\hline D1-3 & 279.6 & 299.0 & 289.3 & 121.5 & & 254.9 & 274.6 & 264.7 & 111.2 & & 91.16 & & 653.4 & あり & 0.617 & 0.686 \\
\hline \begin{tabular}{|l|} 
D2-1 \\
\end{tabular} & 239.0 & 267.1 & 253.1 & 106.3 & \multirow{3}{*}{114.4} & 197.2 & 245.5 & 221.3 & 92.99 & \multirow{3}{*}{103.6} & 82.48 & \multirow{3}{*}{87.15} & 495.0 & あり & 0.559 & 0.520 \\
\hline D2-2 & & 272.6 & 272.6 & 114.5 & & - & 254.2 & 254.2 & 106.8 & & & & 652.8 & あり & 0.642 & 0.686 \\
\hline \begin{tabular}{|l|} 
D2-3 \\
\end{tabular} & 284.0 & 298.3 & 291.1 & 122.3 & & 260.8 & 267.3 & 264.0 & 110.9 & & 91.82 & & 597.0 & あり & 0.565 & 0.627 \\
\hline
\end{tabular}

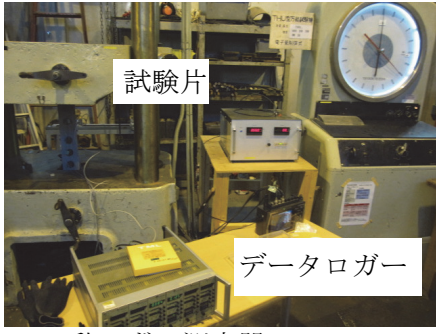

動ひずみ測定器

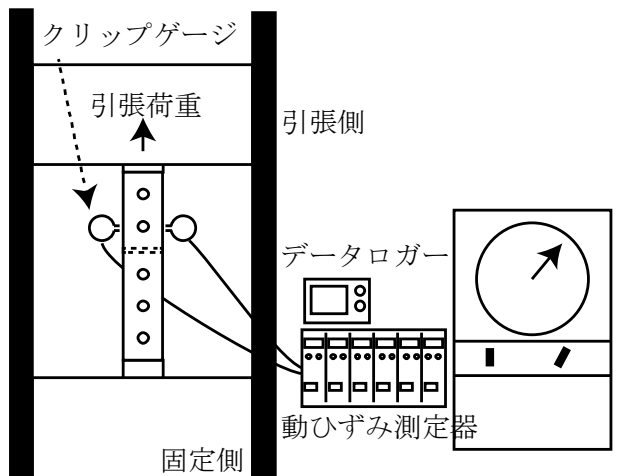

試験機

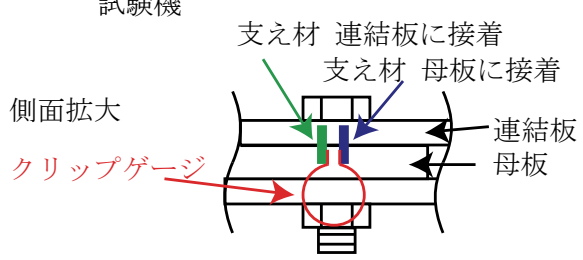

図-12 すべり試験状況

従い行った．なお，固定側(すべらせない側)のボルト については, 120 で締付けた.

\section{(4) すべり耐力試験の方法}

すべり試験は，ボルト締付け720時間後に実施した。 載荷状況を図-12に示す。試験には載荷能力 $2000 \mathrm{kN} の$ THU型万能試験機(東京衡機)を用いた。本試験では, 試験体両端部それぞれ $130 \mathrm{~mm} の$ 範囲をチャックで固定
し，試験体のすべりが生じるまで引張荷重を徐々に加 えた。試験時には，図-11に示すNo.1ボルト位置で母 板と連結板間の相対変位を測定した。図-12にクリッ プゲージ側面の拡大図を示しているが，アクリル製の 支え材を2個使用し，一つを母板に接着，もう一つを 連結板に接着することで相対変位を測定した。クリッ プゲージは動ひずみ測定器およびデータロガーに接続 し，100Hzサンプリングでデータを取得した.

すべり耐力は，荷重が急激に下がるか，荷重の降下 がなくすべりが不明確な場合はボルト位置での相対変

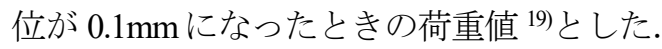

\section{6. すべり耐力試験の試験結果}

\section{（1） ボルト軸力計測結果}

ボルト軸力導入試験結果を表-16 に示す。初期導入 軸力は設計軸力の $113 \sim 133 \%$ となったが，大半が 120\%台になった. 120～130\%となるように，ナット回 転量を決めたのでこの範囲に入ったことになるが，D2 シリーズ，つまり M24-L120 では低めになってしまっ た.

リラクセーション後のボルト軸力は設計軸力の 103 〜 $122 \%$ の範囲となった。軸力の残存率でみると，す べての試験体で 90\%前後になり，10\%を大幅に上回る 低下率とはならなかった。

\section{(2) すべり係数算出結果}

すべり荷重およびすべり係数算出結果を表-16 に示 す.

すべての試験片において，継手部分がすべった際に 大きな音がした。 また, す心゙り音とともに荷重が急激 に低下した．このため, 変位量によるすべりの判定を 


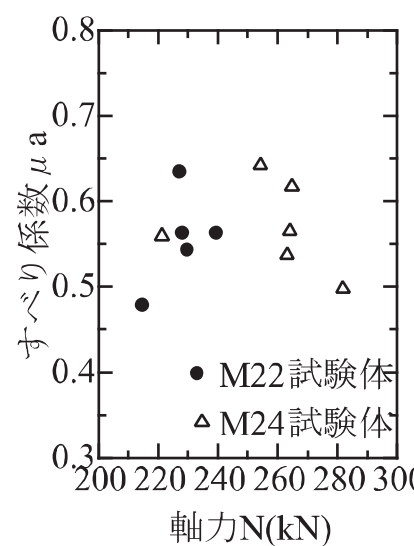

図-13 すべり係数 とボルト軸力

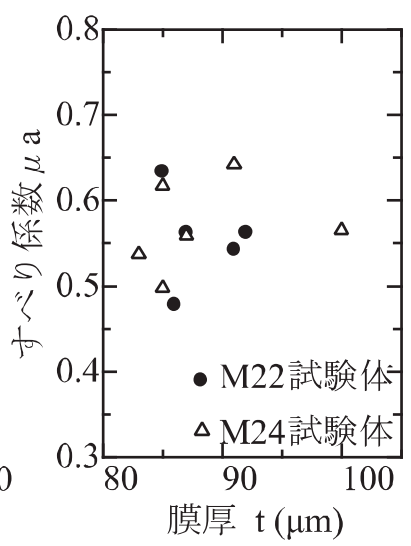

図-14 すべり係数 とジンク厚さ
行う必要は生じなかった。

すべり係数は，式(2)を用いて計算した。ボルト軸 力としては, 載荷直前のボルト軸力 $\left(N_{a}\right)$ を用いて計算 した $\mu_{a}$ と，設計ボルト軸力 $\left(N_{b}\right)$ を用いて計算した $\mu_{b}$ を 示している.

$$
\mu=\frac{P}{n m N}
$$

$\mu:$ すべり係数, $P$ : すべり荷重

$m$ : 接触面数, $n$ : ボルト本数, $N$ : ボル卜軸力

いずれの試験体においてもすべり係数 $\left(\mu_{a}\right)$ は，道路 橋示方書でも示されている無機ジンクリッチペイント 下地 0.45 を上回り，0.48〜0.64 の範囲にあった。 ボル 卜径が太いほうが，また，ボルト長が長いほうがす心゙ り係数が高くなる傾向はみられたが，差はほとんどな いといえる.

設計ボルト軸力を用いて計算したすべり係数 $\mu$ はす ベてのケースにおいて，0.5を上回り，0.5〜0.7の範囲 となった。

\section{(3) すべり係数に及ぼす導入軸力, 膜厚の影響}

すべり係数と軸力の関係を図-13 に，すべり係数と 膜厚の関係を図-14 に示す．軸力が高くなれば，す心゙ り係数も若干低くなる傾向が報告されているが ${ }^{18)}$ ，本 試験ではその傾向は見らなかった。また，一般に膜厚 が薄くなるとすべり係数は低くなり，厚くなり過ぎて も低くなる傾向 12)にあるが，図-14 に示すように本試 験の膜厚のばらつきの範囲程度ではすべり係数には影 響しなかった。

\section{（4）すべり試験後の接触面の観察}

試験体の試験後の接触面(す心゙り面)を図-15に示す. 図-15(a)に示すように，ボルト孔周辺の寸心゙ったと思 われる箇所では無機ジンクの剥離が生じた。塗膜の剥 (a) $\mathrm{C} 1-2$

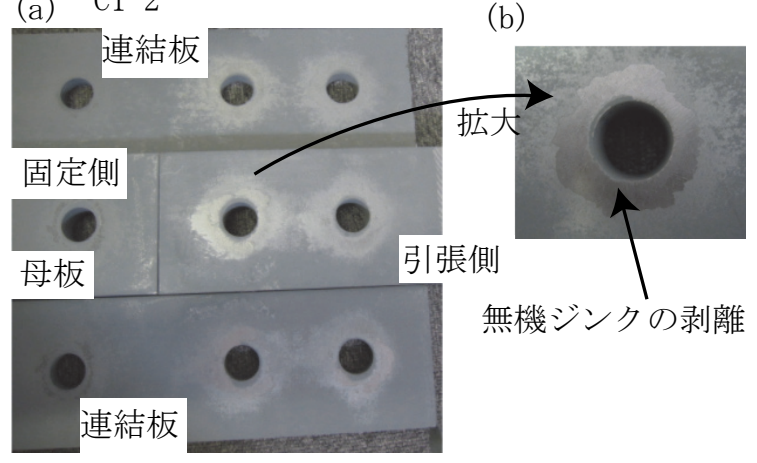

(c) $\mathrm{C} 2-2$

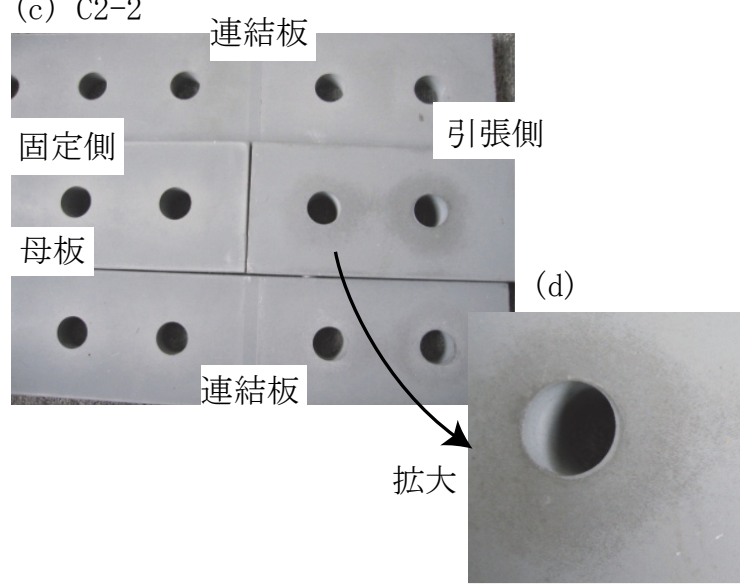

図-15 すべり試験後の接触面の観察

離状況が著しい場合の方が，す心゙り係数は低くなる傾 向となった．図-15(c)に示すように，厚い板では塗膜 剥離の程度が小さかった。また，ボルト孔のこば面に ボルトが接触した状態(支圧状態)になったと思われる 試験体はなかった。

\section{7. まとめ}

本研究では, F10T ボルトのナット回転角法の適用 に向けた検討を行うため, スナッグタイト試験を行い, その後, ボルト径およびボルト長をパラメータとした 導入軸力試験およびリラクセーション試験により適切 な回転角を検討した．提案したナット回転量で再度リ ラクセーション試験およびすべり耐力試験を行った. これら試験結果から得られた主な結論は，以下のとお りである.

(1) スナッグタイト試験で締付けたボルトのトルクは, 鉄道設計標準 2)で規定されている一次締めの值 $(150 \mathrm{Nm})$ で平均值に近いものとなったが，大きくばら ついており，分散值としては $18 \mathrm{kN}$ 程度のばらつきが あった。ナット回転角法の適用に際しては，締付け精 度を向上させるため, 一次締めのトルク值を規定し, 
実施工を行うのがよいと考えられる.

(2) ナット回転量とボルト軸力の間には，ナット回転

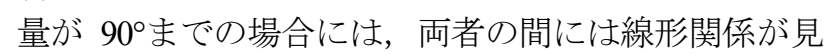
られた。ナット回転量が 90 を超えると, ボルトねじ 部は塑性域(非線形領域)に達するものと考えられる. このときの設計ボルト軸力比は $140 \%$ 程度であった.

(3) ナット回転角法の適用に際し，表-13 に示すように, M22 は一次締め $150 \mathrm{Nm}$ を前提として，ボルト長 $4.1 d$ 以下 $\left(d\right.$ はボルト径)のときは回転角 $90^{\circ}, 4.2 d \sim 5.0 d$ で は $105^{\circ}$ ，また，M24 では一次締め $200 \mathrm{Nm}$ を前提とし て，4.2d 以下のときは $85^{\circ} ， 4.3 d \sim 5.0 d$ では $90^{\circ}$ とする. この回転量であれば，ボルトねじ部は塑性域に入らず, また, リラクセーション後の軸力も設計ボルト軸力を 満足できる.

(4) 提案したナット回転量で, 再度リラクセーション 試験およびすべり耐力試験を行ったが，導入軸力は設 計軸力に対し, 各試験体の平均值は 114～125\%導入さ れることが示された.また，720 時間のリラクセーシ ヨン後の残存軸力は 104～113\%，軸力残存率は 90\%を 保つことが示された.すべり試験を行ったところ，い ずれの試験片に対しても, すべり係数は 0.48 を上回る ことが確認された。

\section{8. おわりに}

これまでのナット回転角法では，ボルトねじ部にお いて塑性域までを考慮した締付け回転角であった。こ のため，遅れ破壊の懸念が叫ばれてきた．ただし，本 研究では, 塑性域に入らない範囲でのボルト軸力であ り，また，トルク法で許容されている上限トルクまで を考慮したナット回転角を提案した。

遅れ破壊の要因は, 材料成分, 拡散性水素量（さび から供給）およびボルト軸力である ${ }^{8)}$.ただし，遅れ 破壊を起こさないための具体的な基準值はないのが現 状である，そこで，本論文では弾性域（概ねトルシア 型ボルトの基準值の最大值程度）に残存軸力を抑えて おけば，遅れ破壊に対するボルト軸力の影響はほとん じなくなると考えた.

提案した回転角の信頼性を高めるためには，さらに 実績を増やし，その締付け精度の検証を進めていく必 要はあると考えている.

謝辞 : 本研究は, 鋼橋技術研究会「高力ボル卜継手施 工部会 : (部会長 : 南 邦明)」の活動の一環で行っ たものである. 本試験の実施において, 鋼橋技術研究 会技術委員会 (委員長 : 森 猛) の委員の方々および 当部会の部会員の方々から数々のご意見・ご助言を賜
りました．また，スナッグタイト試験において，三井 $\mathrm{E} \& \mathrm{~S}$ 鉄構エンジニアリングの濱達矢氏のご協力をい ただきました.ここに記して心より感謝申し上げます.

\section{参考文献}

1) 日本道路協会 : 道路橋示方書 - 同解説一 II 鋼橋 - 鋼 部材編, 2017.11.

2) 鉄道総合技術研究所 : 鉄道構造物等設計標準 - 同解 説(鋼・合成構造物), 2009.7.

3) 西川和廣, 高岡司郎, 菅原一昌：高力ボルト締付け 工法一耐力点法一, 橋梁と基礎, Vol. 24, No. 7, pp. 35-43, 1990.

4) 南邦明, 斉藤雅充, 横山秀喜, 杉本一朗, 能島隆男, 増永寿彦，長崎英二：亜鉛アルミ擬合金溶射を施し た高ボルト摩擦接合継手に関する研究, 土木学会論 文集 A1, Vol. 68, No. 2, pp. 427-439, 2012.6.

5) 南邦明, 吉原伸行, 徳富恭彦, 鈴木茂弘：りん酸塩 処理した溶融亜鉛めっき接合面の高力ボルト摩擦接 合継手におけるナット回転角の提案, 土木学会論文 集 A1, Vol. 69, No. 3, pp. 467-480, 2013.10.

6) 松山晋作 : 遅れ破壊, 日刊工業新聞社, 1989.

7) 日本鋼構造協会 : 高力ボルトの遅れ破壊, JSSC, Vol. 6, No. 52, 1970.4 .

8) 田島二郎, 青木博文, 田中淳夫, 小林昌一, 北後 寿 : ナット回転法の提案, JSSC 協会誌, Vol. 9, No. 89, pp. 17-31, 1973.5

9) 板垣秀克, 和泉公比古 : 回転法の F10T 自適用, 首 都高技報, No. 7, pp. 136-139, 1975.3.

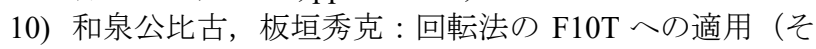
の 2），首都高技報，No. 9, pp. 136-138, 1977.3.

11) 大貫一生 : F10T ボルトの回転法による施工，首都高 技報, No. 9, pp. 130-133, 1977.3.

12) 土木学会 : 高力ボルト摩擦接合継手の設計・施工・ 維持管理指針(案), 2006.12 .

13) 南邦明, 遠藤輝好, 小峰翔一, 吉岡夏樹, 宮井大輔, 涉谷敦, 内田大介：トルシア形ボルト S10T(M22)の 導入軸力および機械的性質の統計調査, 土木学会論 文集 A1, Vol. 74, No. 2, pp. 280-289, 2018.8.

14) 池田秀継, 畑中清 : 耐力点締付法に用いる摩擦接合 用高力ボルトの暴露試験報告, 鋼構造論文集, Vol. 21, No. 84, pp. 1-7, 2014.

15) 橋田芳朗, 橋本郁郎, 今村壮宏, 山下恭敬, 松田哲 夫, 山口弘信 : 38 年供用後の HTB F11T の遅れ破壊 特性, 土木学会第 67 回年次学術講演会, I-344, 2014.

16) 本州四国連絡橋公団, (財)海洋架橋調査会: 工場部構 造委員会報告書, 本州四国連絡橋の海洋架橋技術に 関する調查研究, 1992.3 .

17) 日本建築学会 : 鋼構造接合部設計指針, 2012.3 .

18）南邦明：厚膜型無機ジンクリッチペイントを施した 高力ボルト継手における導入軸力の影響の考察, 土 木学会論文集 A1, Vol. 74, No. 1, pp. 58-63, 2018.

19) 南邦明, 田村洋, 白旗弘実, 内田大介, 吉岡夏樹, 濱達矢 : 高力ボルト摩擦接合継手のす心゙り耐力試験 におけるすべり発生時の変位量, 土木学会論文集 A1, Vol. 75, No. 2, pp. 249-256, 2019.8.

(Received February 14, 2019) (Accepted September 27, 2019) 


\title{
APPLICABILITY OF TURN-OF-NUT BOLTING METHOD FOR FRICTION TYPE CONNECTION BY F10T HIGH STRENGTH BOLT
}

\author{
Hiromi SHIRAHATA, Kuniaki MINAMI, Daichi FUJINO, Daisuke MIYAI, \\ Shota YANO and Wataru YOKOTA
}

This study investigates the applicability of turn-of-nut method by F10T high strength bolt (Tensile strength is $1000 \mathrm{MPa}$ ). Conventionally, turn-of-nut method is allowed only for F8T of lower yielding stress. In addition, torshear type high strength bolt such as S10T also can be found in many constructed works. Though S10T shows good workability, it requires finishing of tip of bolt and daily check of axial force by sampling. Turn-of-nut method of F10T can enhance the efficiency of the bolting process. In this study, at first, snug tight test was carried out by professional fastening workers. The result of axial forces of the bolts varied in a wide range, and the average axial force was almost equivalent with $150 \mathrm{Nm}$ that is specified in railway design code. The appropriate turn-of-nut angle was investigated by the experiment, changing the length and diameter of bolt with the steel plates coated by inorganic zinc silicate primer. The result showed that the bolts get in the yielding area more than 90 degrees. Based on the optimum nut angle from the experiments, relaxation and slip tests were carried out. The one month relaxation test showed that the decrease of axial force of the bolts was ranged within $10 \%$. The slip coefficients by the tests satisfied 0.45 that is specified in Japanese Road Association bridge design code. 